\title{
Colonnaded Hall in Kourion How the Oecus Corinthius Was Interpreted in the Roman Houses of Cyprus
}

\author{
Patrizio Pensabene, Eleonora Gasparini
}

\begin{abstract}
This contribution analyses the architecture of the public reception area of a house in Kourion, on the southern coast of Cyprus. Known as the Early Christian House due to the discovery of a later phase, characterised above all by mosaics, the house, which is only partially excavated, boasts architectural features that date back to the Hellenistic era. These sprang from official Alexandrian models that subsequently spread across the Mediterranean. In territories such as Cyprus, where ties with the Ptolemaic Kingdom were close, this new form of architectural expression continued to flourish, with transformations and elements of innovation, even during the Imperial Age. In the Early Christian House this phenomenon is particularly evident in a colonnaded room in which the model defined by Vitruvius, the Oecus Corinthius appears. In this particular instance, the style is embellished with the use of simplified capitals and angular heart-shaped pillars of the Doric order. The architectural elements of the house are analysed here in order to provide a stylistic and chronological framework what contribute to the reconstruction of the history of the early Imperial phase of the building.
\end{abstract}

Keywords: colonnaded hall, Graeco-Roman Cyprus, architecture, housing, Kourion

Patrizio Pensabene, Sapienza - Università di Roma, Rome; patrizio.pensabene@uniroma1.it

Eleonora Gasparini, Università della Campania 'Luigi Vanvitelli', Caserta;

eleonora.gasparini@unicampania.it; (D) 0000-0002-5922-0716

The study of Roman housing in the cities of Paphos and Kourion raises the need to relate the structures to earlier buildings from the Hellenistic period, which in many cases represent pre-existing edifices from which new residential complexes were created. ${ }^{1}$ The various earthquakes that affected the southern part of Cyprus in the first and early second centu-

\footnotetext{
${ }^{1}$ The introduction, the third section and the Appendix are written by both authors, while the first section is by Eleonora Gasparini and the second by Patrizio Pensabene.
} 
ries $\mathrm{AD}$ caused the destruction of these previous houses and in turn led to their subsequent reconstructions during the early and middle Imperial Age. These reconstructions represent the secondary phase of their use, in which the building or its parts continued to retain some of its Hellenistic characteristics. ${ }^{2}$ Among these, particular attention ought to be given to a reception room, where, either through painting supplemented by stucco reliefs or through the actual construction of columns, a colonnade is suggested that runs along three sides of the room. The fourth side opens towards the peristyle and was divided into three passageways, the central one, the widest, flanked by two lateral passageways, each of which employed actual columns, erected on the same axis as the naves. This type of hall is clearly inspired by the model defined by Vitruvius as Oecus Corinthius, ${ }^{3}$ i.e. a hall characterised by a colonnade composed of more than four elements and developed in a single order. In his definition of this architectural type, Vitruvius does not explicitly mention the kind of order to which the columns must belong. However, the designation given for this type of room obviously seems to be referred to Corinthian colonnades. Conversely, in Cyprus the Corinthian order in internal colonnades seems to appear only in pictorial representations, such as in the 'Hellenistic' House of Nea Paphos, ${ }^{4}$ while real colonnades - at least in examples from Paphos and Kourion known to us - make use of Doric and simplified Corinthian capitals. As a consequence, the Cypriot evidence attests to the possibility of varied realisations of this architectural type. ${ }^{5}$ A fine example of this particular type of reception room in Kourion can be found in the residence located next to the House of the Gladiators (Fig. 1), and excavated by the Department of Antiquities during the seventies. It continued to be inhabited even during the Christian era: hence its name - the Early Christian House. ${ }^{6}$

This paper is aimed at the study of the architecture of this colonnaded hall in the context of the known sector of the house. Through a detailed analysis of the preserved architectural elements, it is possible to get a stylistic and chronological framework of the evidence and to include the data in the broader scenario of the Roman architecture of Cyprus.

2 This theme is developed in: Pensabene, Gasparini 2020.

${ }^{3}$ Cf. Vitr., De arch. VI.3. For an examination of this type of colonnaded hall and the relationship of the Vitruvian text in comparison with the extant remains, see: Cecconi 2020.

${ }^{4}$ Karageorghis 1979: 714, Fig. 88; Młynarczyk 1990: Pl. 40, Fig. 77.

${ }^{5}$ Compare a list of the Oeci Corinthii and Aegyptii (those of Cyprus are missing) in: Cecconi 2020: Pl. I, where the use of Doric capitals never appears.

${ }^{6}$ We would like to thank the Department of Antiquities for granting the permission for carrying out this research. Since at the time of excavation, the wide peristyle in front of the residence had not yet been discovered, it was believed that the complex, called the 'Apsidal Building' or the 'Public Building,' had a public function. Very little information is available about the edifice: Michael C. Loulloupis (Loulloupis 1972: 11, Figs 30-31) discusses the extraction, consolidation and restoration of the mosaic in the apsidal hall, but the site is still referred there to as the House of the Gladiators, both in the text and in the captions of the published images. 


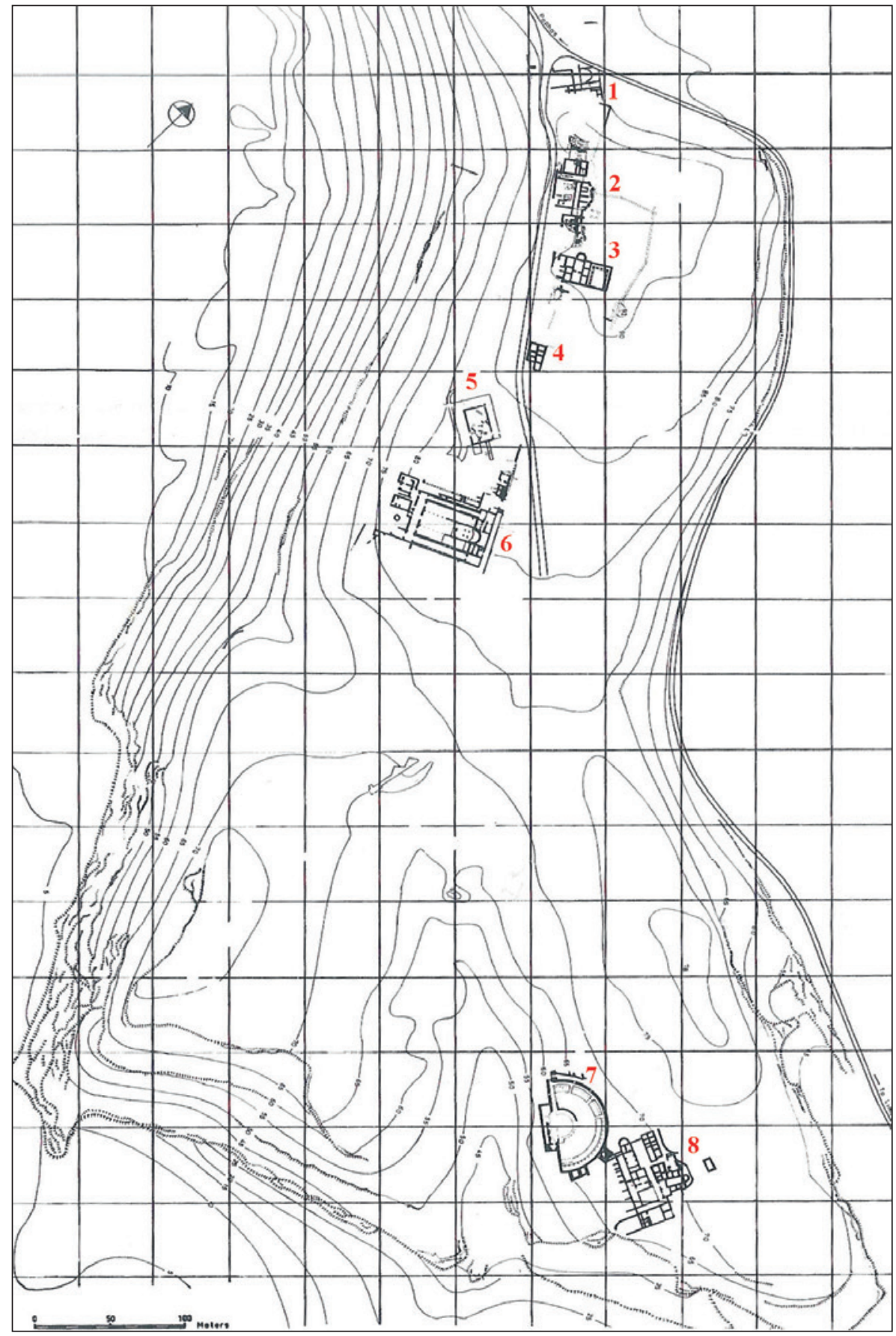

1. Kourion, general plan: 1. Building of Achilles Mosaic; 2. House of Gladators; 3. Early Christian House; 4. Fountain House; 5. Tourist Pavilon; 6. Early Christian Basilica; 7. Theatre; 8. Annexe of Eustolios (based on: Iacovou, Karageorghis 1987: Fig. 1). 


\section{THE RECEPTION AREA AND THE COLONNADED HALL OF THE EARLY CHRISTIAN HOUSE}

The reception area of the Early Christian House consists of an apsidal hall (Fig. 2:2) and, just north of it, a colonnaded one (Fig. 2:1), inspired by the Oecus Corinthius, probably opening into the middle of the western porticoed wing (heading north-south) (Fig. 2:10) of a large peristyle. ${ }^{7}$ Other rooms to the north, beyond the colonnaded hall, remain unexcavated. Nonetheless, a reconstruction of the plan of the complex can be proposed (Fig. 2). ${ }^{8}$

In the preserved part of the peristyle the Attic base of a pillar in one corner was identified (cat. no. 22, Fig. 3) and several large Attic column bases, some of which are still in situ (cat. no. 23). They are all without plinths (Fig. 4).

The apsidal hall is square in plan, its semi-circular apse is pentagonal on the outside. Its marble floor is on higher level than that of the hall (Fig. 5). It is preceded by a vestibule with an opus sectile floor (Fig. 2:3). Access is gained via a tripartite entrance supported by two columns of which the Attic bases remain in situ (cat. nos 20-21). Although the bases are damaged, they clearly lack plinths, while a double torus is visible. The lower-shaft has been carved out of the same block, what allows us to associate them typologically with those of the aforementioned peristyle and the colonnaded room (see also below). ${ }^{9}$

On the western and eastern sides of the apsidal hall are three small rectangular rooms probably intended for serving domestics (Fig. 2:4-9). ${ }^{10}$ On the southern side there are three other rooms in line with southern portico, of which the one in the middle is much narrower. It is not clear if they faced the street, but if they did they may well have been tabernae.

Finally, the aforementioned porticoed wing of the peristyle must have continued to form an angle with the southern wing that has not yet been excavated (Fig. 2:11). Nevertheless, at the place presumed to be the western limit of the southern wing, there is an underground, vaulted area. Since the floor above the vault is at the same level as the peristyle, we have defined it as a cryptoporticus (Fig. 6).

Besides the opus sectile in the vestibule and the apse, a part of the polychrome mosaic floor with a geometric pattern has also been preserved in the apsidal hall (Fig. 7). It has been compared to that of the nave of the Basilica of Soloi, in its second phase, dating to the

\footnotetext{
${ }^{7}$ The main axis of the house is oriented NW-SE, but here we follow the previous publications conventionally indicating the side along the modern street as the southern one. An ambulatory, $4.5 \mathrm{~m}$ wide and excavated for a length of 30m, was interpreted to be a street: 'Le grand bâtiment (15,6 x 18,5 m) est situé en bordure d'une rue (côté Ouest) qui traverse du Nord au Sud la colline de Kourion. Cette rue, pavée de pierres concassées liées avec du mortier' (Karageorghis 1974: 893). In the same report (Karageorghis 1974: 894) the colonnaded hall is mistakenly considered to be an open-air courtyard whose floors are described as being decorated with black and white mosaics in the small naves and with 'dalles de marbre' in the central area.

${ }^{8}$ For the plan of the house, see also: Buell, Mavromatis, Parks 2010: 290, Fig. 3.

9 'La façade du vestibule comportait deux colonnes au centre et des piliers aux coins: des bases de colonnes d'ordre ionique sont encore in situ' (Karageorghis 1974: 893).

${ }^{10}$ Christine Kondoleon, in: Wylde Swiny (Ed.) 1982: 104.
} 


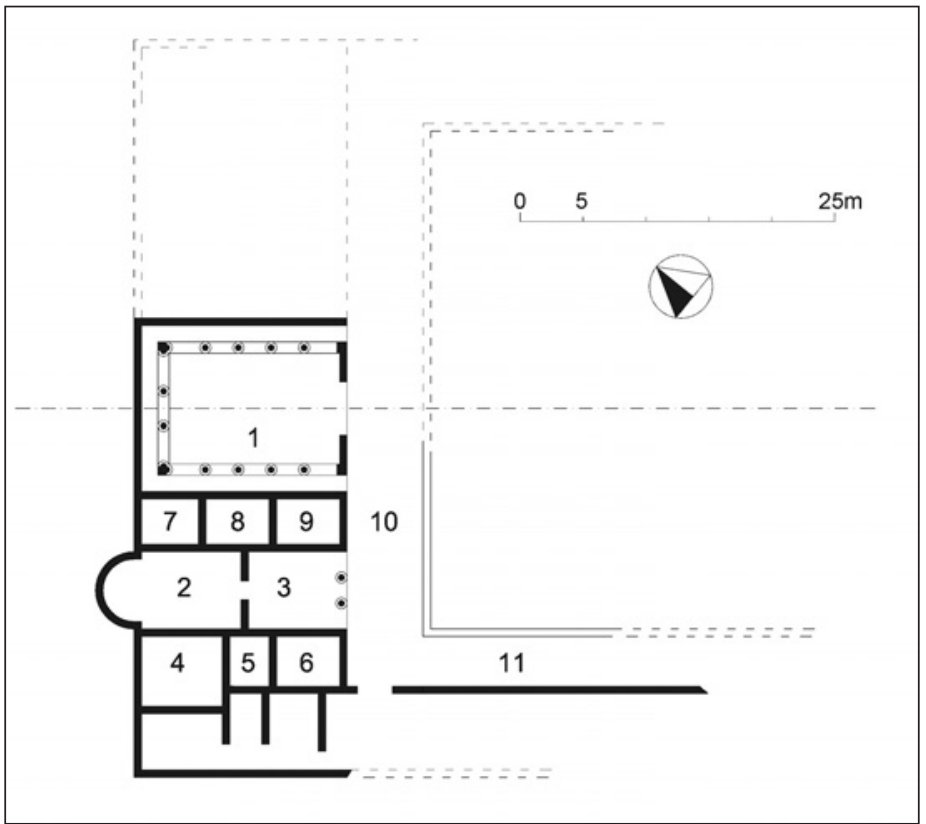

2. Early Christian House, general plan: 1. colonnaded hall; 2. apsidal hall; 3. vestibule; 4-9. small (serving domestics?) rooms; 10 . western ambulatory of the peristyle; 11 . southern ambulatory of the peristyle/cryptoporticus (Drawing: E. Gallocchio; based on: Iacovou, Karageorghis 1987: Fig. 1).

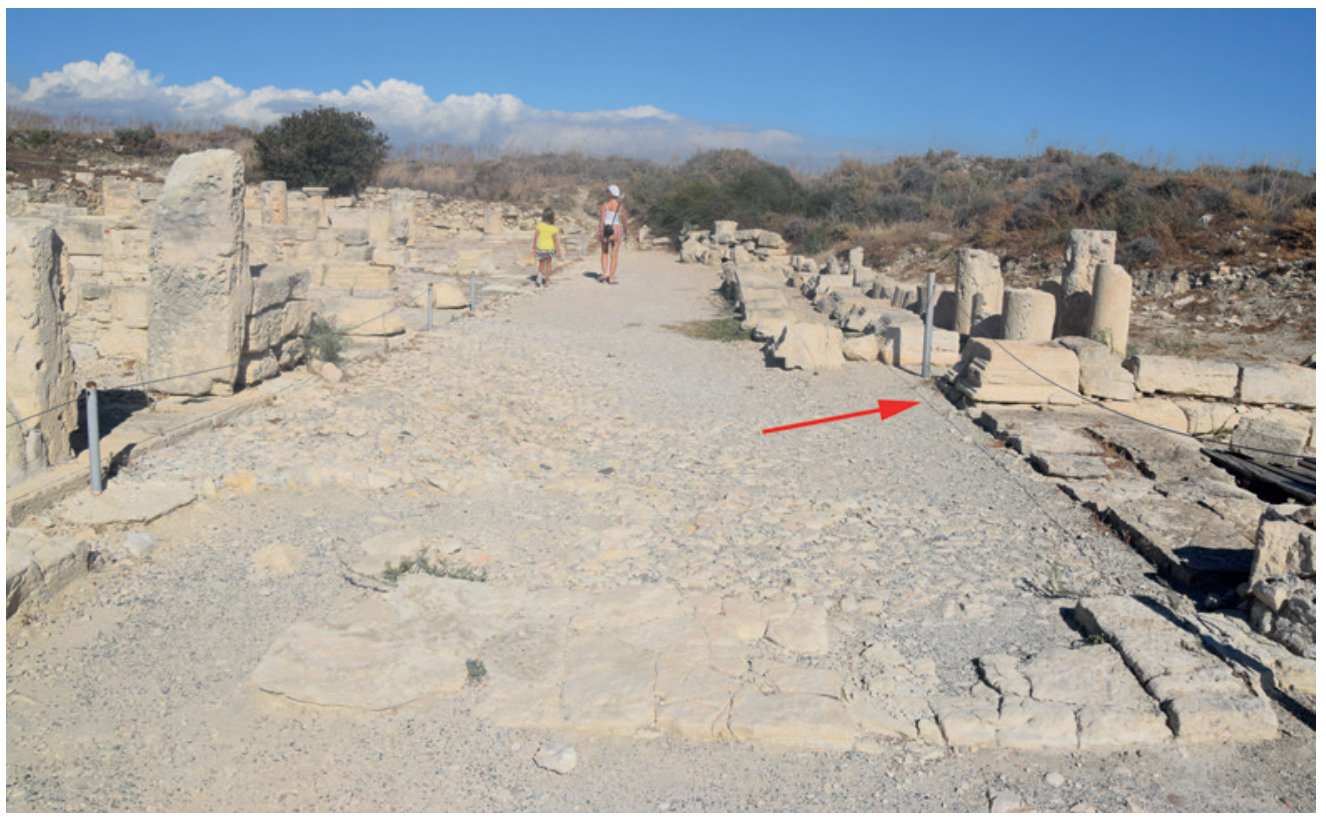

3. Western ambulatory of the peristyle: in the foreground, entry threshold to the ambulatory; the arrow indicates the Attic base of an angular pillar (cat. no. 22) (Phot. P. Pensabene). 


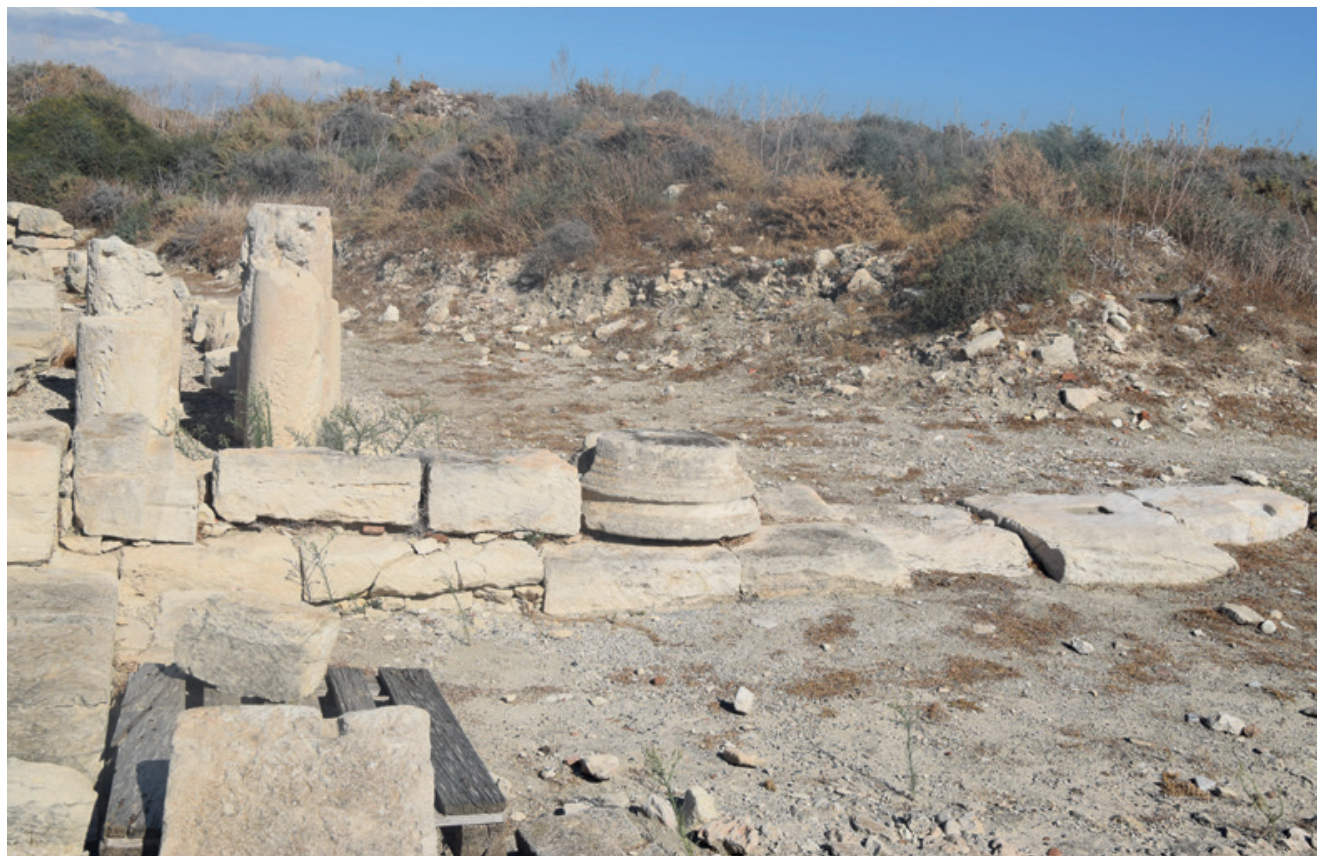

4. Southern stylobate of the peristyle colonnade with an Attic column base (cat. no. 23) resting on it (Phot. P. Pensabene).

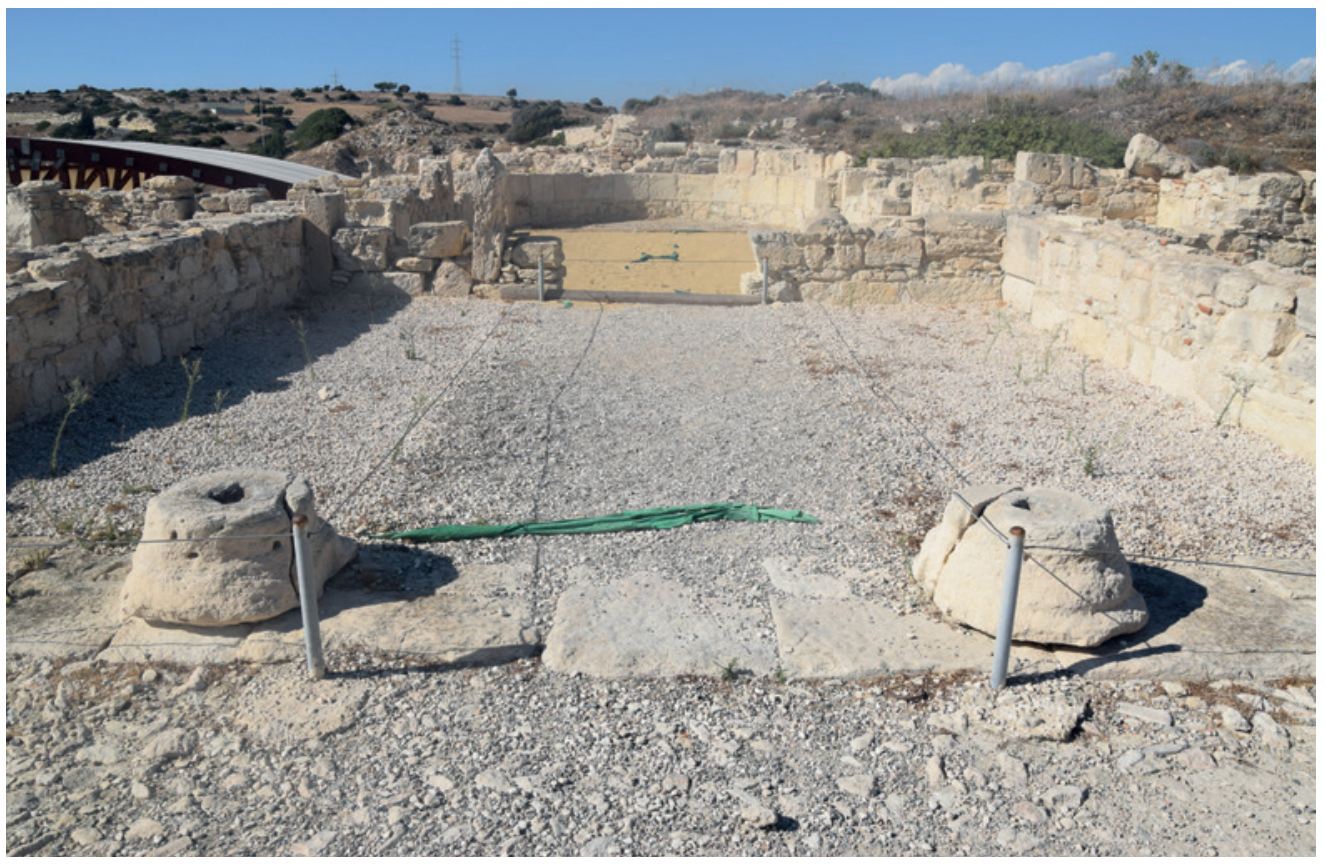

5. Vestibule of the apsidal hall: in the foreground, tripartite entrance with column bases (cat. nos 20-21) (Phot. P. Pensabene). 


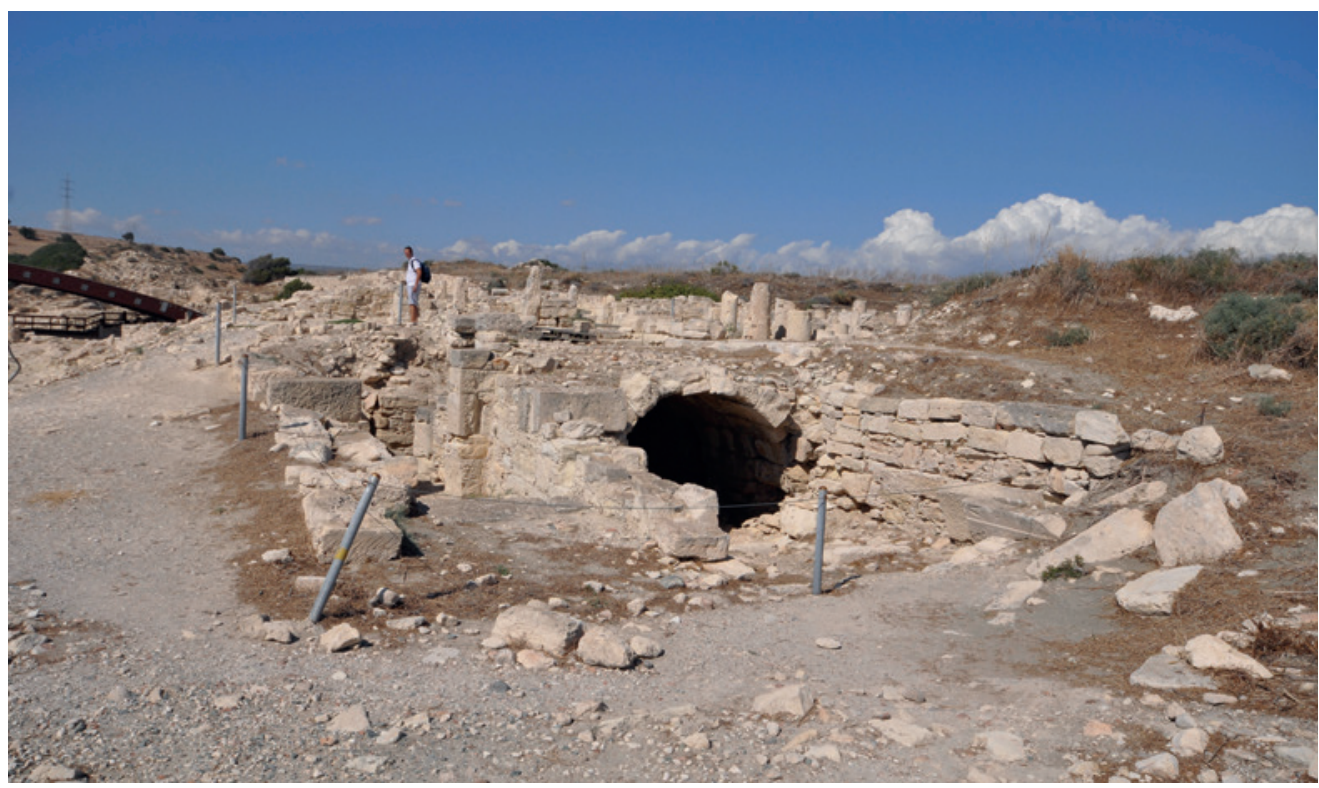

6. Cryptoporticus under the southern ambulatory of the peristyle (Phot. P. Pensabene).

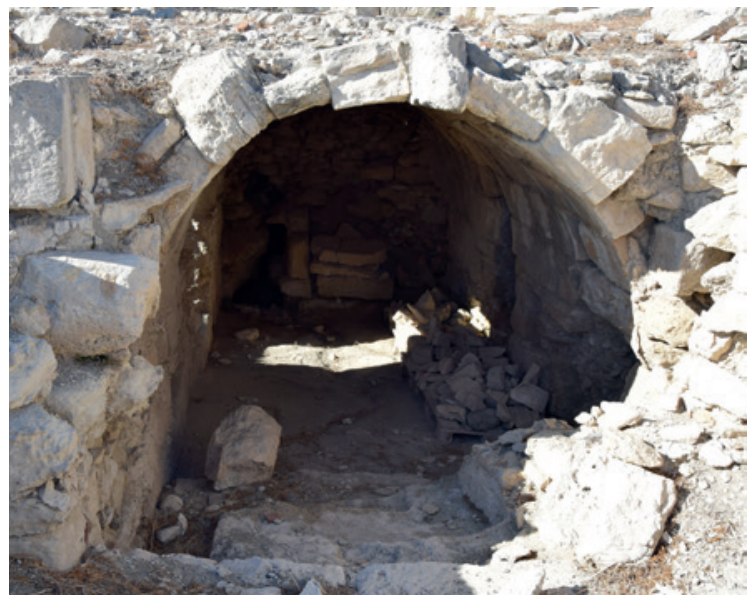

beginning of the fifth century AD. However, the discussed one from Kourion is considered to be slightly later and should therefore be compared also to the floor from the sixth century AD Baptistery of the Basilica of Kourion. ${ }^{11}$ Other black-and-white geometric mosaics from the same period have been found in the side rooms of the Early Christian House.

11 Within a field of tangent quadrilobes containing peltae between the petals (Balmelle et al. 1985: 41), two emblemata occupy the centre of the room. These are represented in one instance by a 'pin-wheel' motif framed by a two-band guilloche (Balmelle et al. 1985: 38, 42) and in another by a duck that is about to peck a pomegranate inside a laurel wreath crown, adhering to an iconography of the classical tradition, but rendered in a stylised way (Michaelides 1987: 45-46, Pl. XXXII, Fig. 52a-b; 1988: 93, 95, 130-131, 138, Figs 4 and 54). 


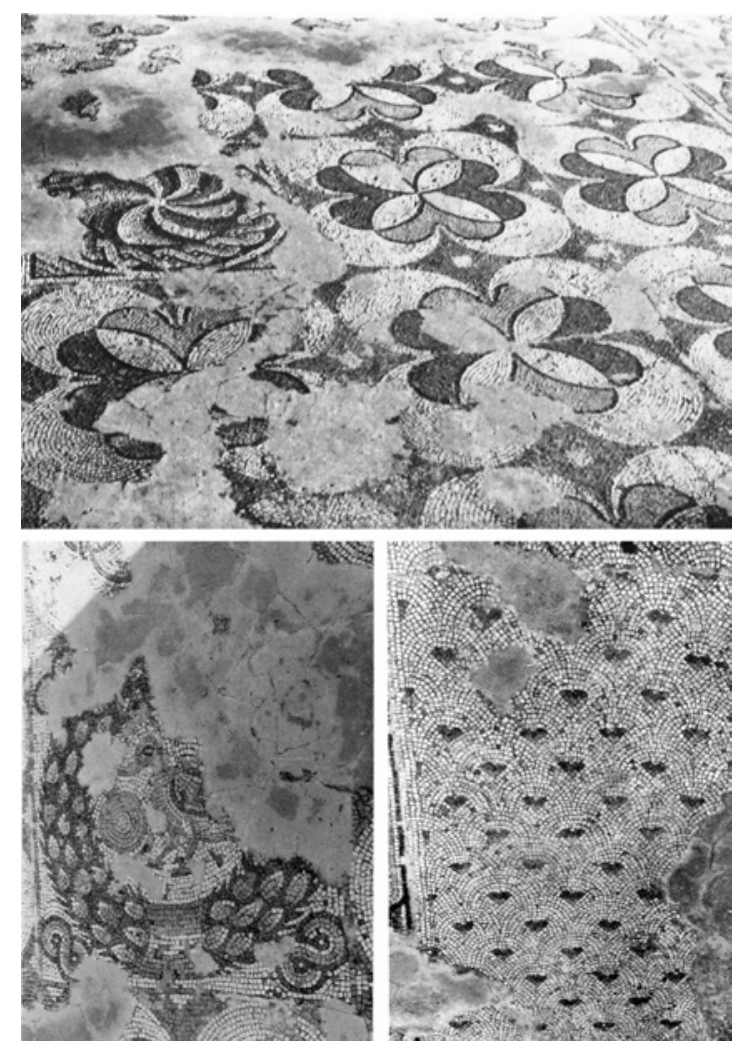

7. Mosaic patterns from the apsidal hall (Michaelides 1987: Pl. XXXII, 52a-b; 1988: 138, Fig. 54).

Thanks to the discovery of coins from the Constantinian era above the mosaic floors, ${ }^{12}$ the Early Christian House was initially dated to the second half of the third century. The mosaics, however, show that the last phase of occupation was still later. ${ }^{13}$ The Doric

The central field is bordered by two further geometric motifs: one of these has a semis of florets on a background of scales. This motif appears in mosaics of Antioch that are securely datable to the sixth century, although examples from Lebanon would appear to date to the fourth century (Michaelides 1987: 134 including bibliography for Palestinian examples). In the case of the Early Christian House, the motif appears in a variant in which the peltae are not bordered by tesserae of a different colour from that of the background. Instead, they are rendered exclusively by the design itself, unlike what is commonly observed in other Cypriot examples, where the peltae are outlined by dark coloured tesserae. In any case, both variants of the motif can be found in Kourion, within the sixth century baptistery of the basilica (Michaelides 1987: 139, Fig. 55), while the one appearing in the Early Christian House is also found in the Basilica of Ayia Trias in Yialousa. The variant with the outlined peltae features twice in the Basilica of Soloi, where it seems to be attributable to the third phase, that is to say from the late fifth-early sixth century (Michaelides 1987: 130-133). In addition to the semis of florets, the central motif is also bordered by an interlace, forming a series of pairs of ellipses (Michaelides 1987: 46). For an interpretation of these motifs, defined as 'characteristically late patterns', see most recently: Michaelides 2020.

${ }^{12}$ Michaelides 1988: 93.

13 'bâtiment de la fin de l'époque romaine' (Karageorghis 1974: 893). See also Michaelides 1987 and 1988, where it is also hypothesised that the edifice might have had a public function. 
8. Doric capital (cat. no. 19) embedded in the masonry of the apsidal hall (Phot. P. Pensabene).

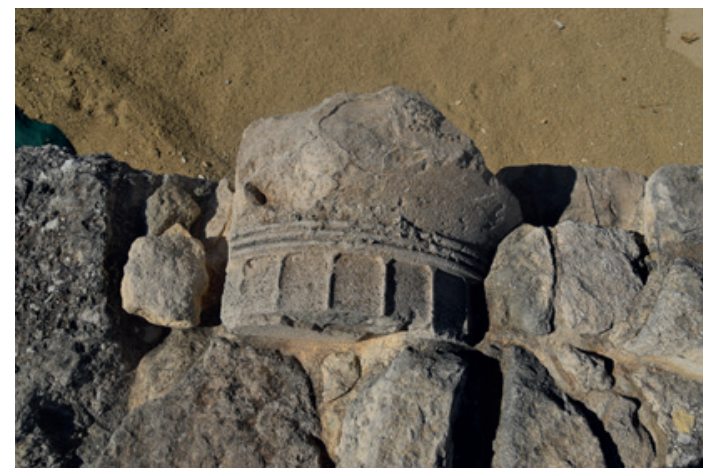

capital (cat. no. 19, Fig. 8), embedded into the masonry of one of the sides of the apsidal hall, certainly predates the mosaics: the conical echinus, the three anuli below, of which the lower one is fused with the astragal of the upper-shaft moulding, together with the flat fluting, all point to the late first century BC.

We must highlight that the chronology of the mosaics of the room with the apse is not coherent with the dating of the architecture of the house, which functioned and was preserved until late antiquity. It can be deduced that the apsidal hall and probably also the Corinthian oecus were built or rebuilt after the earthquake in Flavian times. ${ }^{14}$ This catastrophe led to the destruction of a previous colonnade, to which belonged the Doric capital reused in the masonry of the room with the apse and which, due to the presence of the three anuli, is certainly older than those of the colonnaded oecus (see below).

Many of the architectural elements of the colonnaded hall have been found in the area of their original location and the walls preserved in some places even till the maximum height of about $1.50 \mathrm{~m}$ (Fig. 9).$^{15}$ The hall could be accessed through three entrances, the central one of which was wider (4.20 m wide, $0.85 \mathrm{~m}$ deep) than the side ones (about $1.80 \mathrm{~m}$ wide). The two latter allowed entry via the narrow naves between the colonnades and walls (Fig. 10). In the slabs forming the thresholds to the central and side entrances there are quadrangular sockets for pivot posts (Fig. 11). The reason for doors in these passages was motivated by the necessity to protect the room from the wind that frequently rages on the island: they allowed a closing of the reception rooms especially when banquets or other ceremonies were taking place there.

The counter-façade had two flat pilasters placed against the jambs of the two narrower side portals and these would have been aligned with the two lateral colonnades and as wide as the stylobate colonnade (Fig. 12). Two other narrower flat pilasters decorated the inner side of the jambs of the central portal. The bases of these flat pilasters can be

14 Sinos et al. 1990: 23. For the evidence of an earthquake at Paphos under the reign of Hadrian, see: Nicolaou 1967: 106-108; Młynarczyk 1990: 33 n. 41.

15 Karageorghis 1974: 894 observed that 'Toutes les bases, y compris celles des piliers... ont été trouvées in situ sur leurs piédestaux, portant encore parfois les premiers tambours de leurs colonnes lisses’. 


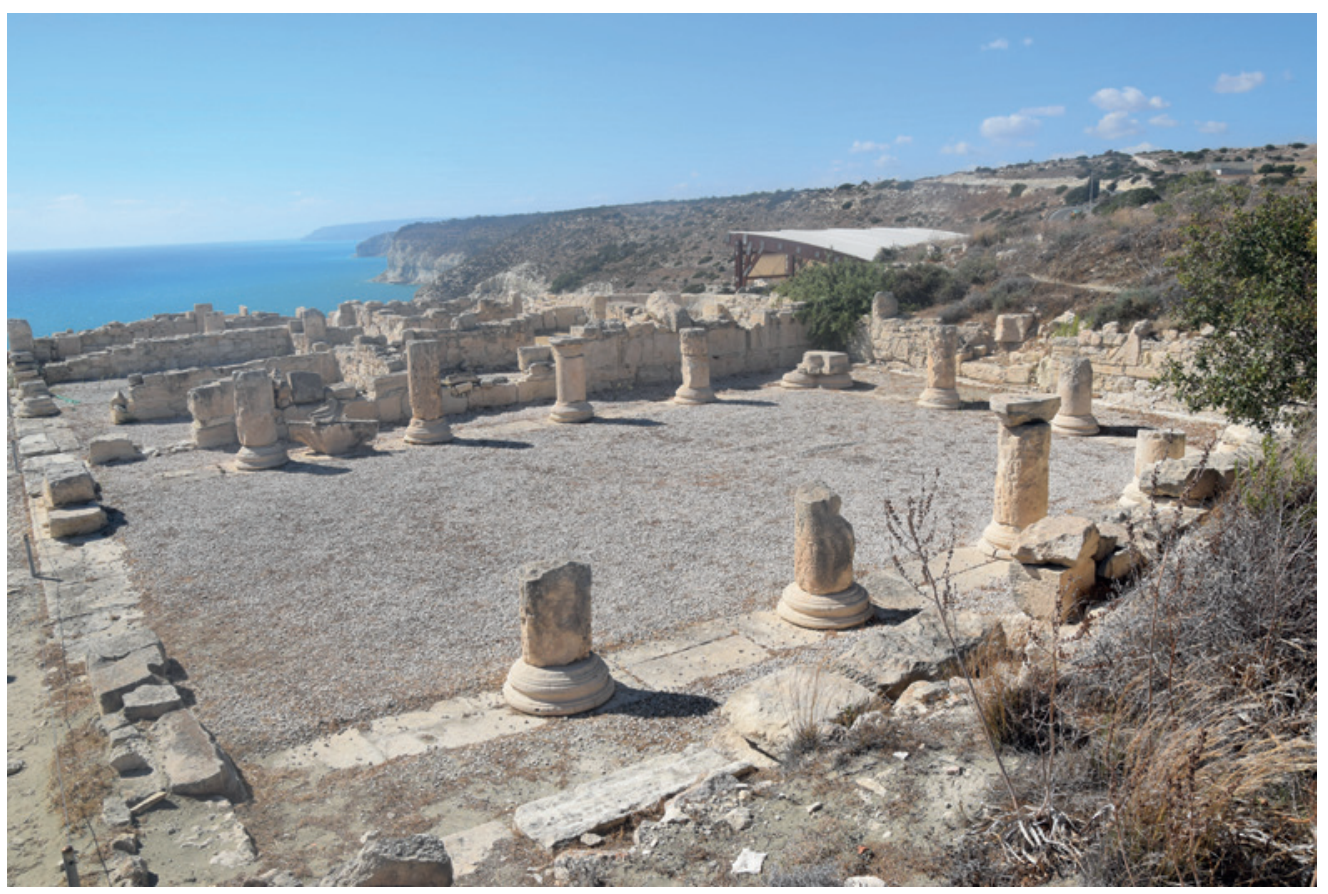

9. Colonnaded hall, view from north-east (Phot. P. Pensabene).

seen on the lower blocks of the jambs, but it should be noted that only on the jambs of the side portals does the body of the flat pilaster itself actually protrude. In the case of the central portal, however, only the bases protrude from the jambs, of which only the lower blocks remain (Fig. 13). The three-sided colonnaded oecus on the fourth side was delimited by a pseudo-colonnade formed by the above-mentioned pilasters on the side jambs of the counter-façade. In the wall on the opposite side a gap in the masonry could indicate a second - narrower and more decentralised - opening, but it is not clear if it is original.

In the corners of the hall there were heart-shaped pillars (cat. nos 1-3) with Doric capitals. Along the walls, at a distance of $1.30 \mathrm{~m}$ from them, rows of columns with simplified Corinthian capitals were situated, of which two have been preserved (cat. nos 8-11). The pillars and columns rest on stylobates that are $1.18 \mathrm{~m}$ from the walls. In summary, the colonnade consists of four columns on the north and south sides and only two columns on the west side; at the corners there are two heart-shaped pillars (Figs 9-10).

However, it cannot be excluded that the two architectural orders were applied at the same time in this area, since some further columns have been found there, now kept in the lapidary in front of the hall (Fig. 14). These were smaller than the ones reconstructed in the original position. Given the height that the two orders could have possibly reached, it might be suggested that this was an Oecus Aegyptius, that is to say, a room with two orders built one over the other along the walls. If this is the case, then the counter-façade 

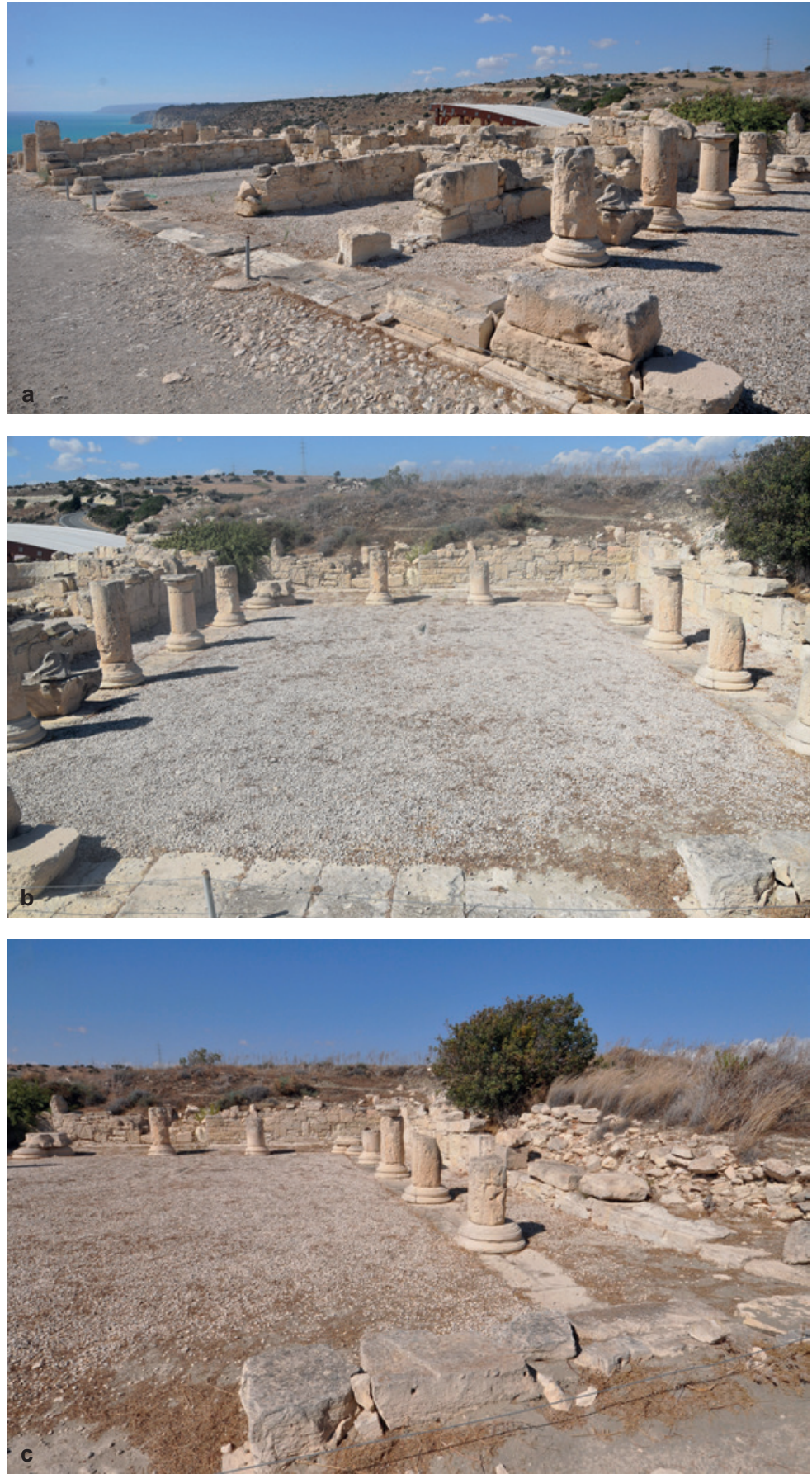

10. Colonnaded hall: a. south-eastern corner, with the sequence of rooms and the western ambulatory of the peristyle; b. threshold of the central entrance; c. north nave (Phot. P. Pensabene). 


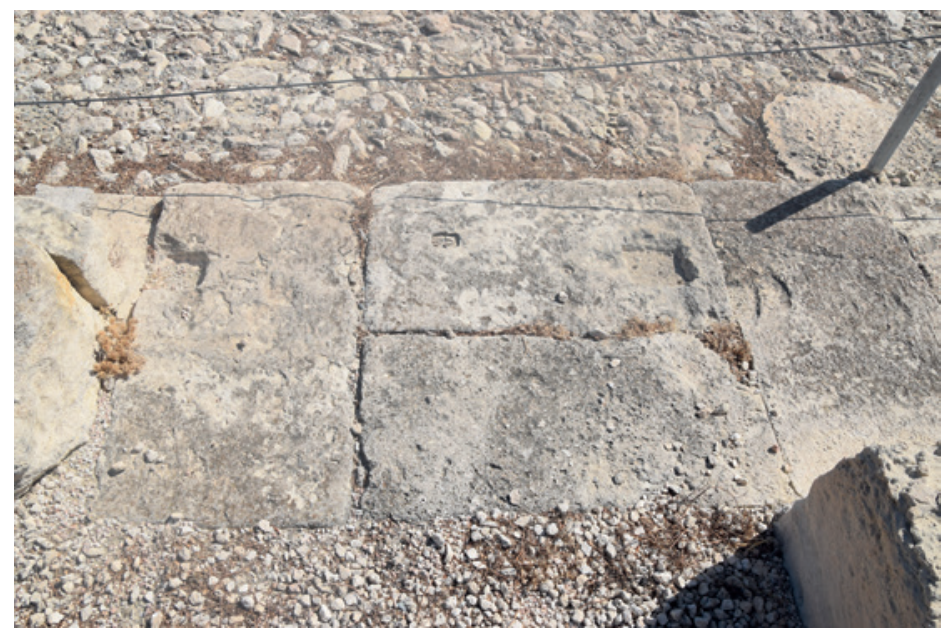

11. Southern opening of the colonnaded hall (Phot. P. Pensabene).
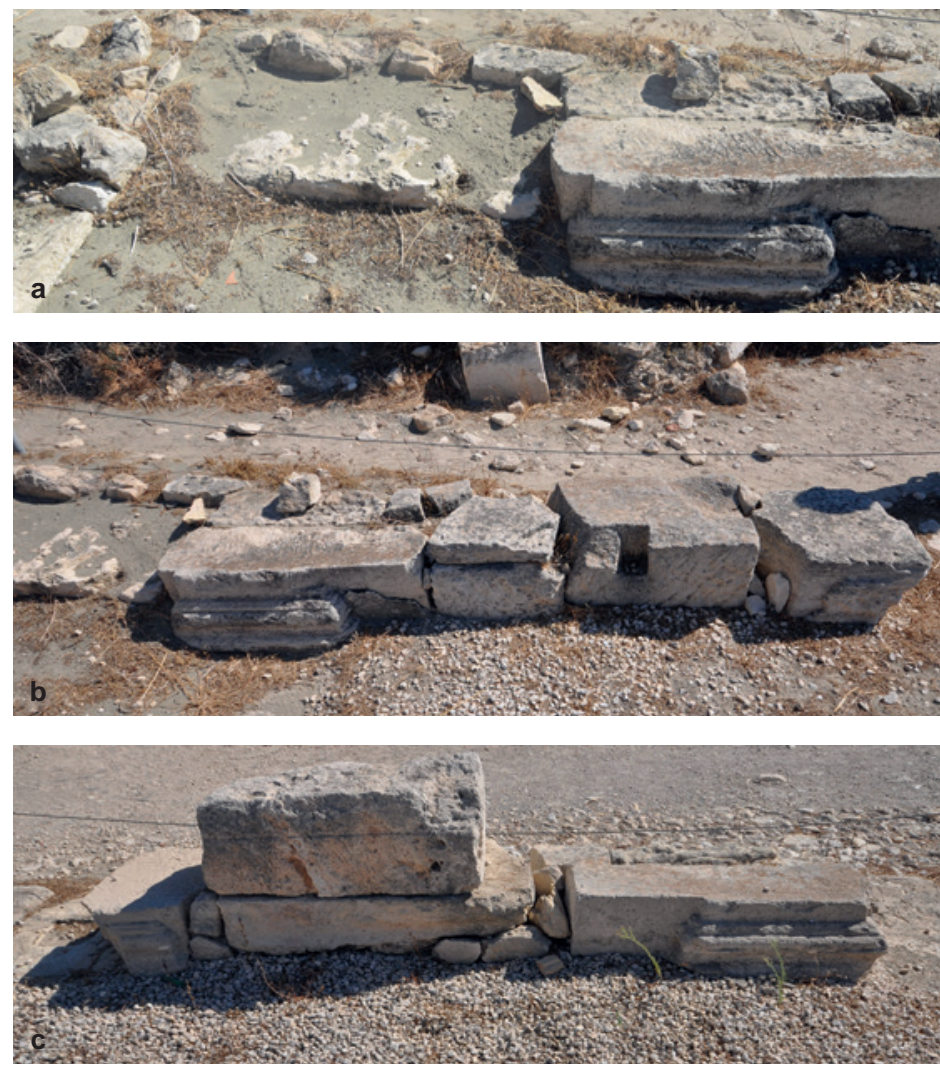

12. Counter-façade of the colonnaded hall: a. northern entrance; b. wall between the northern and the central entrance; c. wall between the central and the southern entrance (Phot. P. Pensabene). 

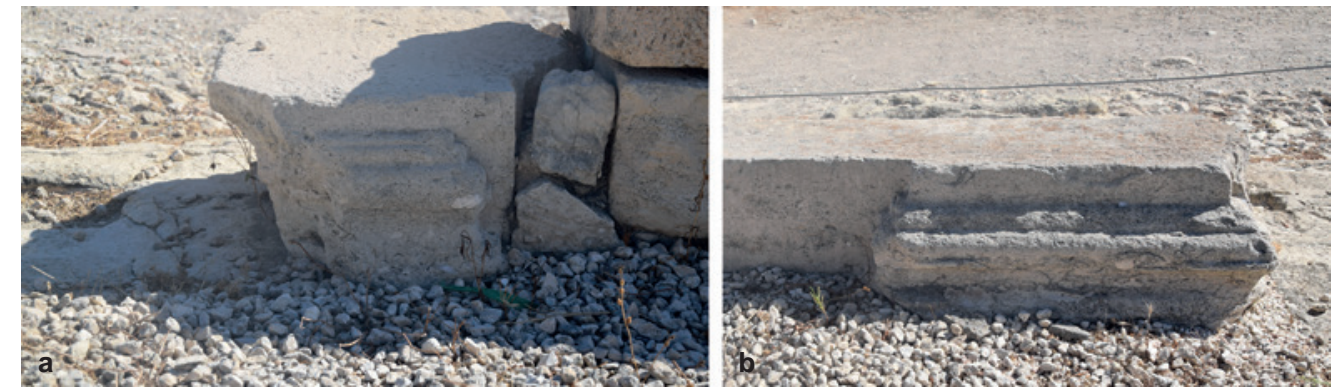

13. Counter-façade of the colonnaded hall: a. central entrance, pilaster on the south jamb; b. south entrance, pilaster on the north jamb (Phot. P. Pensabene).

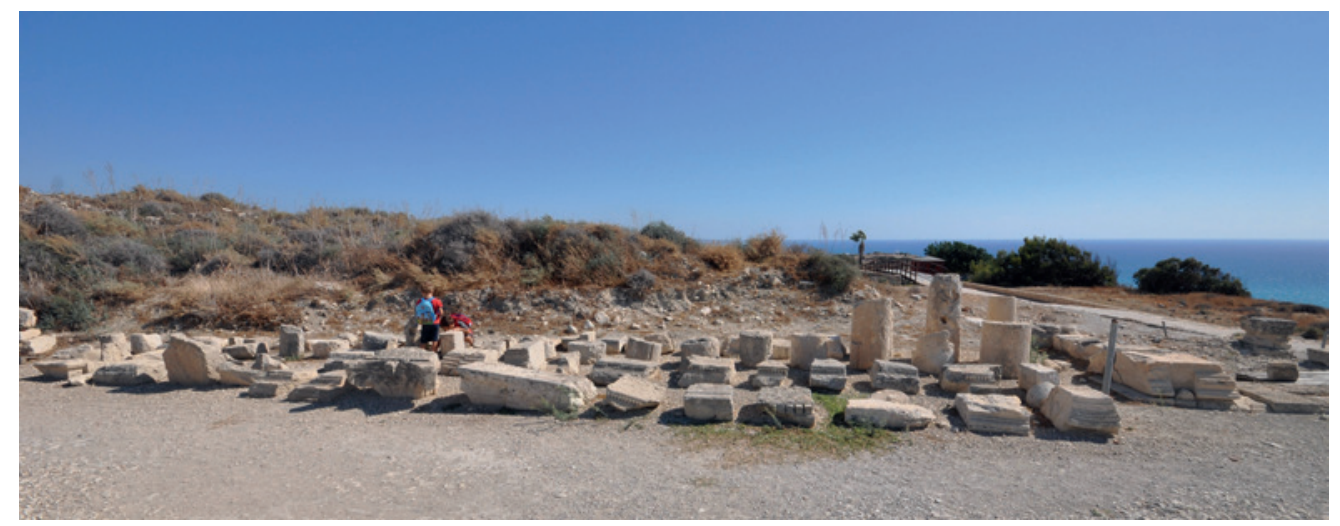

14. Lapidary along the western ambulatory of the peristyle (Phot. P. Pensabene).

would have had been continued above the three portals and was either plain or decorated with flat pilasters.

From a typological point of view, the columns differ from the heart-shaped pillars: the former have Attic bases with two tori, without plinths and simplified Corinthian capitals (so-called Nabatean). The lower halves of these have been repositioned on the third column on the south and north sides, while the upper parts are still discarded on the ground. The heart-shaped pillars ${ }^{16}$ also have Attic bases, similar to those of the columns, but with Doric capitals of the Cypriot type, that is, with anuli transformed into fasciae that overlap - with increasing breadth - with the reduced echinus.

${ }^{16}$ Cf. Vitr., De arch. VI.3. For a comparison of their specific shape see the notable example of the Oecus Aegyptius of the Palazzo delle Colonne in Cyrenaica. There mouldings that mark engaged flat pilasters are also attested. However, the form of the heart-shaped pillars in the great peristyle of the palace is different since they are without protruding flat pilasters (Pesce 1950: Pl. XI). 


\section{ARCHITECTURAL ELEMENTS OF THE ELEVATION}

The excavations of the house, as already mentioned above, have brought to light many elements of the elevation of the colonnaded hall, most of which are now in a lapidary in the western portico of the house. While many of these pieces were found in situ, it seems that others come from the so-called cryptoporticus and were part of a filling created after its abandonment. All the elements are made of local calcarenite.

Large vertical grooves were carved on one of the heart-shaped pillars (north-west corner, cat. no 1a-b), both on the back, so in front of the west wall of the hall, and on the half-capital in front of the next column of the north colonnaded side (Fig. 15a-b). The same feature appears on the simplified Corinthian capital (but only in the lower part; see cat. no. 9) now relocated on this side of the colonnaded hall (Fig. 15c, and below Fig. 20a). ${ }^{17}$ These grooves denote the simultaneous use of Doric and Corinthian orders in the hall. They were probably used to insert partitions or fixtures for curtains or perhaps wooden perforated screens or hangings, which would have screened off specific parts of the aisles. ${ }^{18}$ Conversely, screens at the lower level would have presupposed the existence of additional holes on the bases and on the half-bases of the heart-shaped pillars, which are not attested.

Only on one half-capital of the two heart-shaped pillars (cat. no. 3), now sitting upon the heart-shaped half-bases (cat. no. 2) in the south-west corner, could one observe the crowning of a protruding pillar. The latter bears the same mouldings of the Doric half-capitals but is straight (Fig. 16). In this case there is therefore no correspondence between the half-capitals and the half-bases, as these do not have a protruding pillar. As a result, either the half-capitals are out of place, in the sense that they do not correspond to the half-bases on which they are now placed, ${ }^{19}$ or the pillar protruded only at the back of the half-capitals, without continuing along the shaft of the heart-shaped pillar. In this second case, the crowning would have protruded towards the wall of the south nave and perhaps would have supported a reinforcing arch. The possible presence of this arch in the south nave, together with evidence of partitions or curtains shielding the north nave would significantly modify the interior layout and break the symmetrical and linear scheme of the colonnades in order to respond to specific functional needs.

Two other Corinthian capitals of the simplified type may have been placed on the pillars on the sides of the central portal of this hall. Two upper parts are preserved in the lapidary (cat. nos 12-13, Fig. 17a-b) and one of them reveals a broken rear and the sides of the

${ }^{17}$ No grooved upper part of the simplified Corinthian capitals has survived. Since it is presumed that the upper parts of the Doric half-capitals and the simplified Corinthian capitals must have been on the same level, one must necessarily assume that the upper parts of the simplified capitals with a groove (at least one) which must have been placed on top of the lower part of the simplified capital with a groove, have been lost.

${ }^{18}$ It cannot be excluded that the other columns on this side were surmounted by simplified capitals with grooves. If this was the case, it could be assumed that, possibly at a later date, the spaces between the columns on this whole side were closed-off by hanging elements. On this topic see: Stephenson 2014.

${ }^{19}$ It is hard to conceive that they crowned the jambs of the three portals of the façade, especially since there is no correspondence between the half-capitals and the bases of the flat pilasters. 

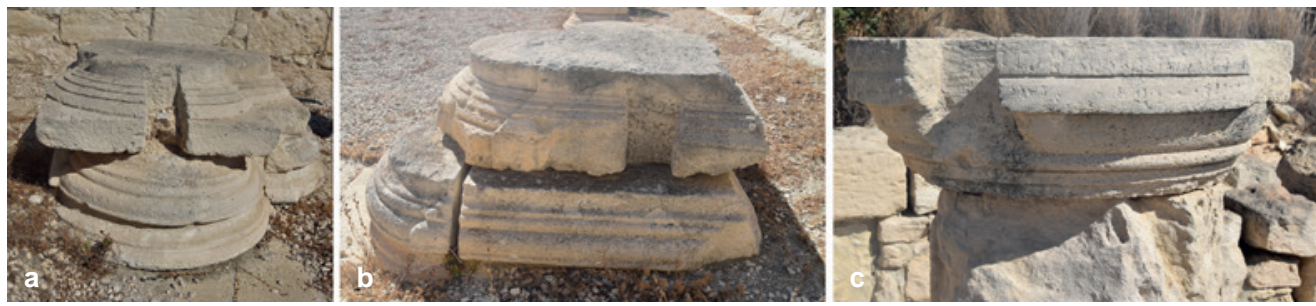

15. Colonnaded hall: a-b. Attic half-bases and Doric half-capitals of the north-west heart-shaped pillar (cat. no. 1); c. simplified Corinthian capital (the so-called Nabatean; cat. no. 9), relocated to the northern colonnade (Phot. P. Pensabene).
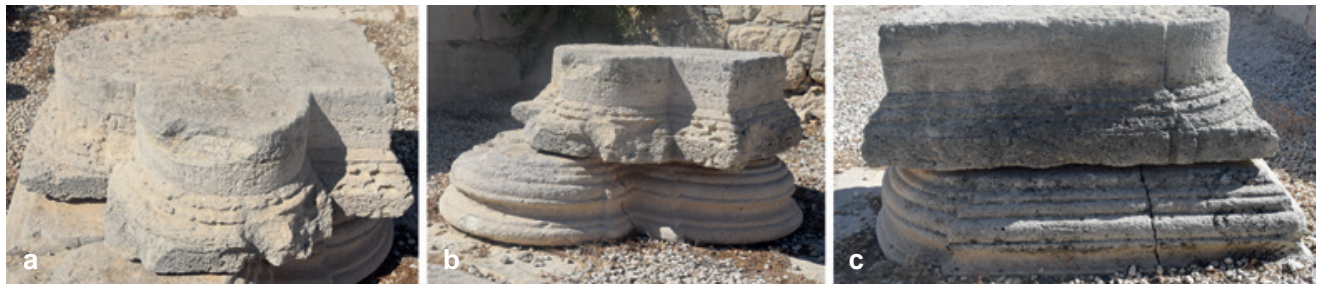

16a-c. Colonnaded hall: Attic half-bases (cat. no. 2) and Doric half-capitals (cat. no. 3) of the south-west heart-shaped pillar (Phot. P. Pensabene).
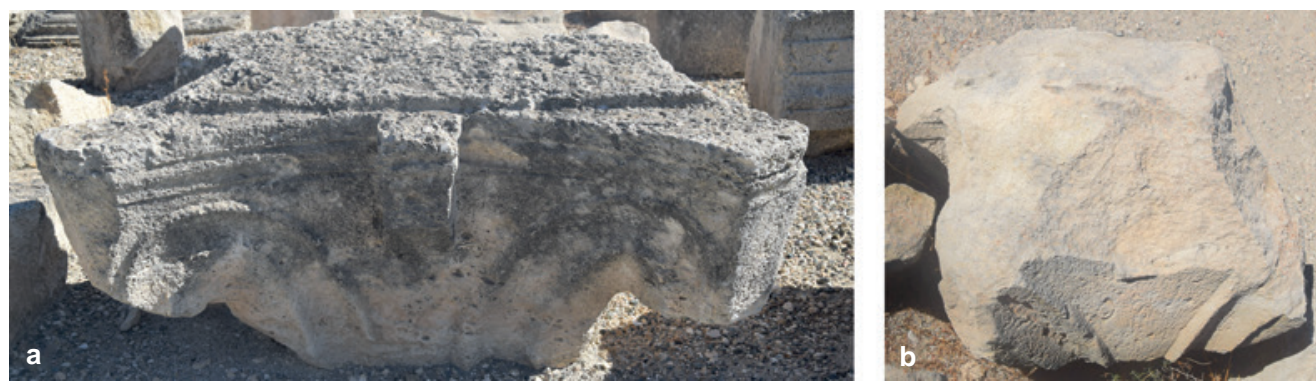

17. Simplified Corinthian capitals (the so-called Nabatean) from the lapidary along the ambulatory of the peristyle, upper parts (a. cat. no. 12; b. cat. no. 13) (Phot. P. Pensabene).

abacus (cat. no. 12, Fig. 17a) less curved than those of the other preserved in the hall (cat. no. 10), so it could have fitted on a pillar. This example also differs from the one now in the hall due to the presence of a scamillus on the upper side of the abacus.

Whatever the case may be, the architectural elements of this room allow one to formulate two conclusions:

1. At the time of construction, there was the capability or interest to carve Doric capitals (of the mid Imperial Cypriot type, with anuli in shape of degrading bands invading the echinus) for the heart-shaped pillars.

2. As for the Corinthian capitals, the Alexandrian order ${ }^{20}$ was abandoned in favour of a new type of simplified capital produced by the local workshops when large capitals were required.

${ }^{20}$ On the Alexandrian-Corinthian order, see: Pensabene 1993. 


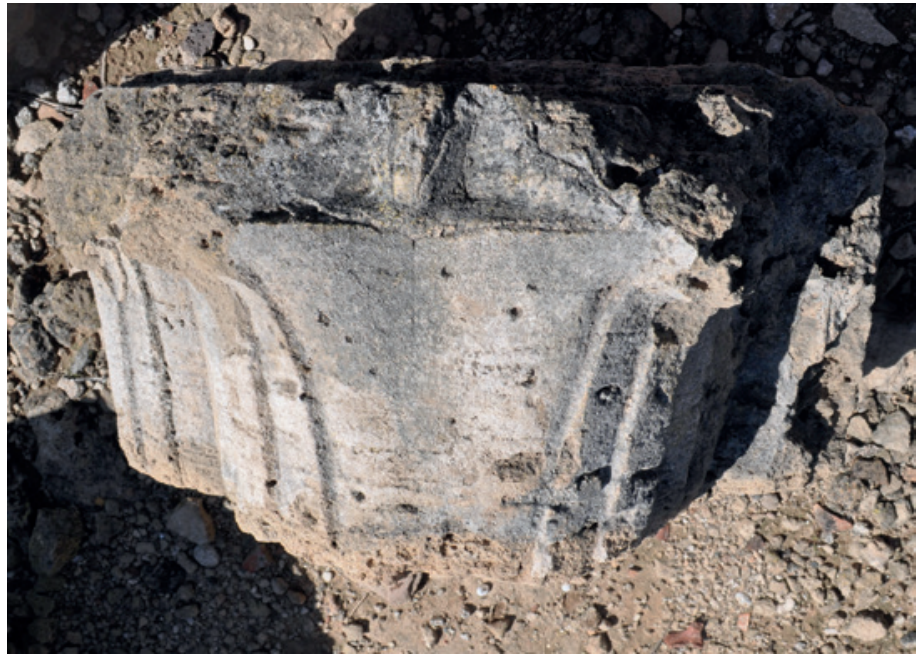

18. Nea Paphos, House of Dionysos: engaged half-capitals on a pillar (Phot. P. Pensabene).

They are the result of the simplified rendering of the Alexandrian Corinthian capitals, from which the use of long water leaves was resumed for the volutes. In addition, the detailed finishing of the acanthus leaves was omitted and the decoration of the central part of the kalathos was left plain. This was confirmed by the discovery of two engaged half-capitals on a pillar that had been reused in the masonry of a large house to the west of the House of Dionysos in Nea Paphos (Fig. 18). ${ }^{21}$ Given the similarity of elements reused in the walls of this complex with those of the oecus with columns along the walls examined here, in Paphos one can reconstruct a situation similar to that of Kourion.

\section{BASES}

The Attic bases of the columns are carved out of the lower-shaft (Figs 9-10). This shows a round astragal and fillet, while the bases are characterised by a wide scotia that is just higher than the lower torus and bounded by two listels of which the upper one is quite thick; the upper torus appears reduced and separated from the listel by only an incision. In the southern colonnade, they are $29 \mathrm{~cm}, 23 \mathrm{~cm}, 33 \mathrm{~cm}$, and $29 \mathrm{~cm}$ high respectively, where the difference in height depends on the greater or lesser height of the astragal cut into them.

The bases of the heart-shaped pillars (cat. nos 1-2) are the same as those of the columns. At the inner corner and the outer sides of the pillar, the mouldings protrude and so differ from those of the bases of the half-columns (Figs 15b, 16c, 19). It can be assumed that the ledge continued in the higher portion of the pillar in order to indicate an engaged low-relief flat pilaster.

The bases are composed of two blocks. They were not cut along the diagonal of the pillar, however. In fact, in the pillar of the north-west corner the cut was made at one of

21 Pensabene forthcoming. 
19. Attic half-bases and Doric half-capitals of heartshaped pillar (cat. no. 1a-b) from the north-west corner of the colonnaded hall (Phot. P. Pensabene).

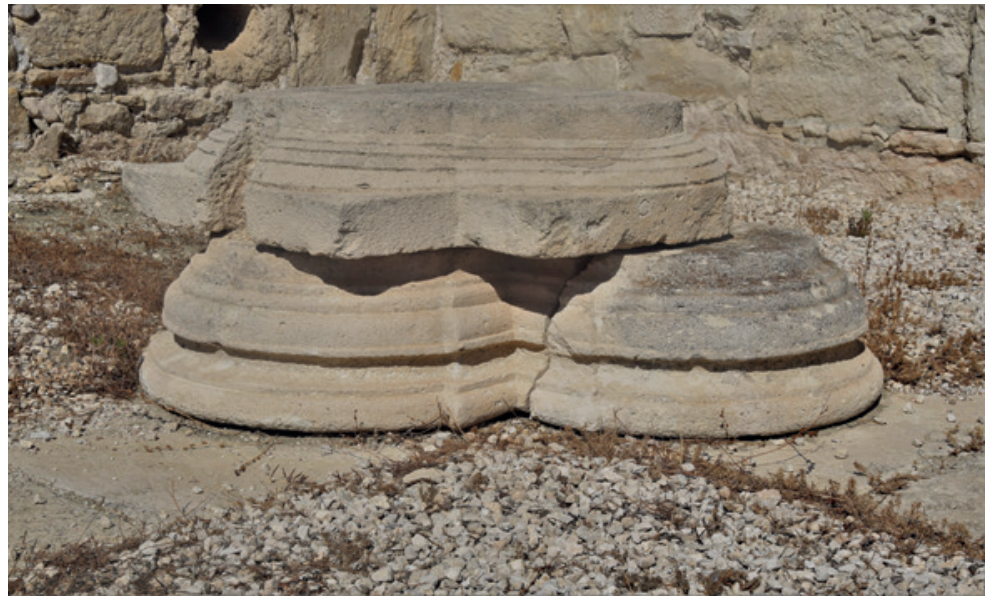

the half-bases, so this block also contains the extremities of the mouldings of the pillars (Fig. 15b), while the pillar in the opposite corner was cut in such a way as to divide this pillar also into two (Fig. 16c).

The bases of the pilasters of the tripartite entrance are moulded with tori, listels and scotia and appear to be carved together with the shaft of the pilaster and the pillar behind it (Fig. 13b). It should be noted that upon the jambs of the central portal, the pilaster bases abutting the inner sides are very narrow (Fig. 13a). The principal side of the jambs was therefore the one that lined the passage between them. Both on this side and on the external side no bases can be observed, and it is possible that the decorative system of the portal was different.

\section{DORIC CAPITALS}

The Doric half-capitals relate to the two half-columns and to the remaining part of the heart-shaped pillar, which has the same mouldings. These mouldings are also found in the crowning of the above-mentioned protruding pillar leaning against the back of the half-capitals (cat. nos 1-3, Figs 15b, 16c).

The half-capitals present a thin and flat cavetto that is in the position of the astragal of the upper-shaft, together with two thin fasciae that replace the anuli and a slightly higher one that replaces the echinus (Figs 15, 16, 19). The result of this sequence corresponds to four bands that are paratactically touching, thus completely transforming the traditional structure of the Doric capital. The abacus that surmounts them has plain sides (total height $25 \mathrm{~cm}$, sides $98 \times 94 \mathrm{~cm}$ ).

As noted above, in the north-west pillar (cat. no. 1a-b) one of the half-capitals has a groove (width $13 \mathrm{~cm}$ ). The same element is observed on the opposite side of the pillar (Fig. 15a-b): the objects originally inserted into these cavities (curtains? screens?) closed the north nave. 
It should be stressed that the greater or lesser protrusion of the mouldings allowed the structural distinction between the half-columns, the engaged pilasters and the heart-shaped pillars behind them.

\section{SIMPLIFIED CORINTHIAN CAPITALS}

The simplified Corinthian capitals (the so-called Nabatean), ${ }^{22}$ as is usual in this type, had been carved in two separate parts. In the colonnaded hall the lower parts had been relocated on the intermediate columns (cat. nos 8-9, Fig. 20) of which some drums are preserved. The overall height of the capitals is just over $70 \mathrm{~cm}$.

The lower part - lower than the upper part - was carved in the same block as the upper shaft of the column and moulded with a thin cyma and astragal. The lower part of the kalathos is shaped with a cyma recta surmounted by two cylindrical disks divided by a horizontal groove.

The lower parts of these capitals show, therefore, how it had been decided to finish the capitals in a more simplistic way, that is to say, with a cyma recta and two disks instead of an array of leaves. The preserved elements are also not exactly the same since one - of which half remains showing a clamp hole on its upper face (north side, cat. no. 9, Fig. 20a) - includes only the moulding of the upper shaft and has a less developed cyma recta. In the other lower part (south side, cat. no. 8, Fig. 20b), however, the upper shaft also includes a section of the column and the cyma recta is more slender.

In addition to these two parts, perhaps a third should also be taken into account (cat. no. 27, Fig. 21). This is no longer in its original position and was probably found in the cryptoporticus, where it is currently located. This shows a less advanced level of workmanship in that the kalathos was never moulded as a cyma recta. Instead, it forms a cylindrical disk, distinguishable from the upper ones thanks to its smaller diameter.

The upper part, which is higher, includes the four plain leaves that support the corners of the abacus. The sides of the abacus arch boldly and are moulded with a cyma reversa and a listel that continue right on to the top of the flower of the abacus, the lower part of which, however, impinges over the kalathos and is in the shape of a parallelepiped protrusion resting on a cyma reversa.

As regards the upper parts one notes: one specimen in the oecus (cat. no. 10, Fig. 22, a corner of its abacus, cat. no. 11, is detached and rests on the capital itself); ${ }^{23}$ another two in the lapidary in the peristyle wing, one of which is complete (cat. no. 12, Fig. 17a), albeit fractured at the back, and the other with the corners of the abacus broken off and missing (cat. no. 13, Fig. 17b); the corner of another is preserved in the cryptoporticus (cat. no. 26, Fig. 22, top left corner). The two complete ones (cat. nos 10 and 12, Figs 22

22 See Wright 1992: Pl. 308.1 where a comparison with an example discovered in Paphos, close to what was formerly the Apollo Hotel, can be found (Fig. 308.2). For the reconstruction of the capital, see: Grawehr 2017: 109, Fig. 5.f; 2019: 41, Fig. 9.d with further bibliography.

${ }^{23}$ It is reproduced in: Karageorghis 1974: 894, Fig. 80. 

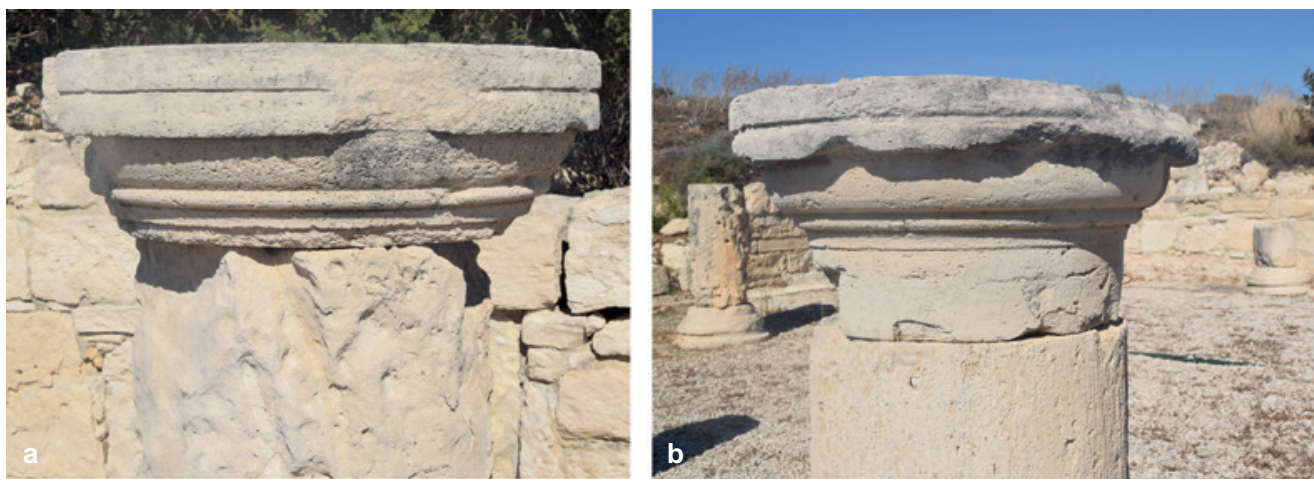

20. Simplified Corinthian capitals (the so-called Nabatean), lower parts, from the colonnaded hall: a. north side, cat. no. 9; b. south side, cat. no. 8 (Phot. P. Pensabene).

21. Simplified Corinthian capital (the so-called Nabatean), lower part, from the cryptoporticus (cat. no. 27) (Phot. P. Pensabene).

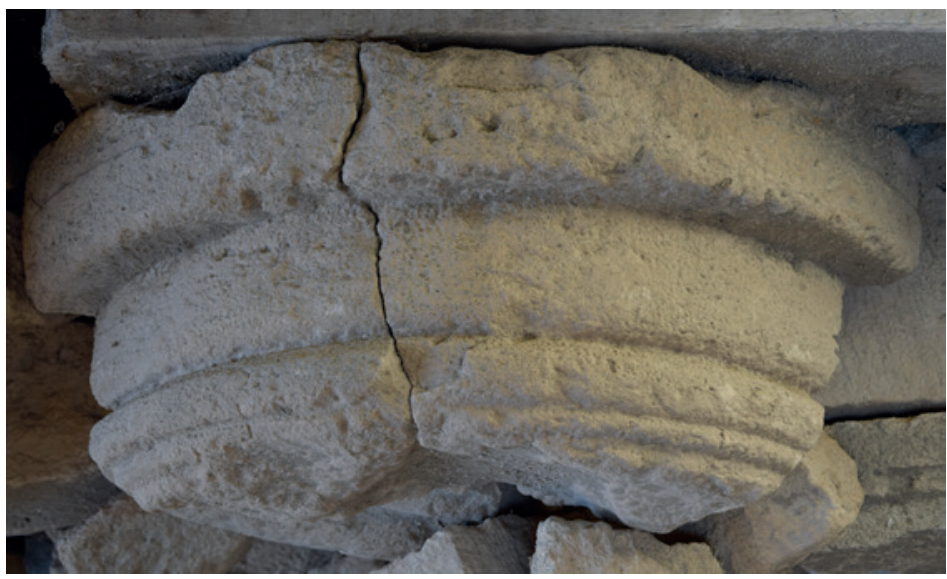

and 17a) differ due to the presence in one - situated in the lapidary - of a scamillus that protrudes over the upper surface of the abacus.

The angular leaves that support the corners of the abacus are divided into three zones: the concave central one and the lateral ones with a convex section. It is also noted that the top of these linguiform leaves folds down toward the central area of the kalathos. But, above all, it should be stressed that the leaves are not structurally separated from the kalathos, but only superficially sculpted onto it. This blocked-out shape of the volutes is enhanced by the sector beneath the corners of the abacus, where the space between the fold of the leaf tips and the corner has a large rectangular shape that appears to be an extension of the kalathos and not part of the leaves. Such a geometric rendering is no doubt due to the fact that the capitals were only partly finished when they arrived from the quarry and since similar elements were found at the Xylophagou quarry. ${ }^{24}$

${ }^{24}$ Karageorghis 1969: 498-499, Figs 135-136. 


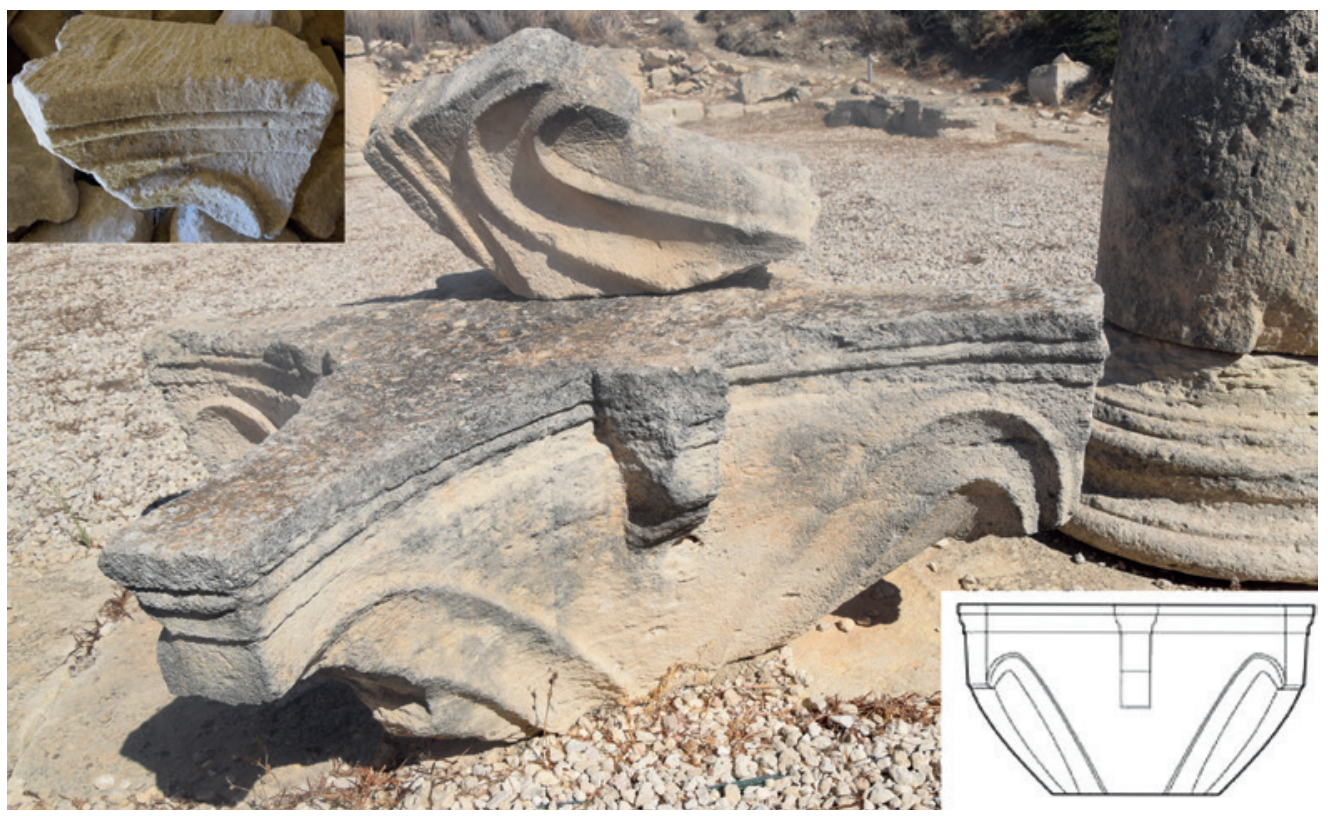

22. Simplified Corinthian capitals (the so-called Nabatean), upper parts, from the colonnaded hall (cat. nos 10-11) and from the cryptoporticus (cat. no. 26; top left corner) and the reconstruction (lower right corner) (Phot. P. Pensabene; Grawehr 2019: 41, Fig. 9d).

\section{IONIC CAPITAL}

The capital (cat. no. 24, Fig. 23) is characterised by the stylistic differences in its key component parts: classicising abacus, with wide elegantly rendered volutes and a reduced echinus with irregular Ionic cyma. In fact, the abacus is decorated with a modelled and refined semi-naturalistic Lesbian cyma with heart-shaped leaves separated by overturned palmettes of which only the central rib emerges. The volutes are executed with well-drawn spirals (consisting of two revolutions) and connected by a channel with a slightly arched lower border. The echinus is made with an Ionic cyma that is divided into three eggs. The eggs are unnatural narrow, elongated and blunt-ended. Only the central egg is whole, while the other two lateral ones are more or less hidden by the spiral of the volutes. On the left, rising from the corner between the spiral and the channel of the volutes, one can distinguish a rough and small half-palmette.

The stylistic differences that have been observed may be the result of a reworking of the echinus at a later date. Comparisons with other capitals from Tamassos, dating to the Hellenistic age, would suggest that our specimen was executed at the same time, but by different hands. One ought to recall the capital of a votive column of the sanctuary of Aphrodite-Cybele (now in the open-air lapidary of the Cyprus Museum at Nicosia), executed with wide volutes similar to ours, but with five eggs. ${ }^{25}$ Moreover, the rendering

${ }^{25}$ Wright 1992: Pl. 293.1-2 (discovered in the foundations of the Hellenistic sanctuary and deemed by Wright to belong to the Classical Age). 
23. Ionic capital (cat. no. 24) from the cryptopoticus (Phot. P. Pensabene).

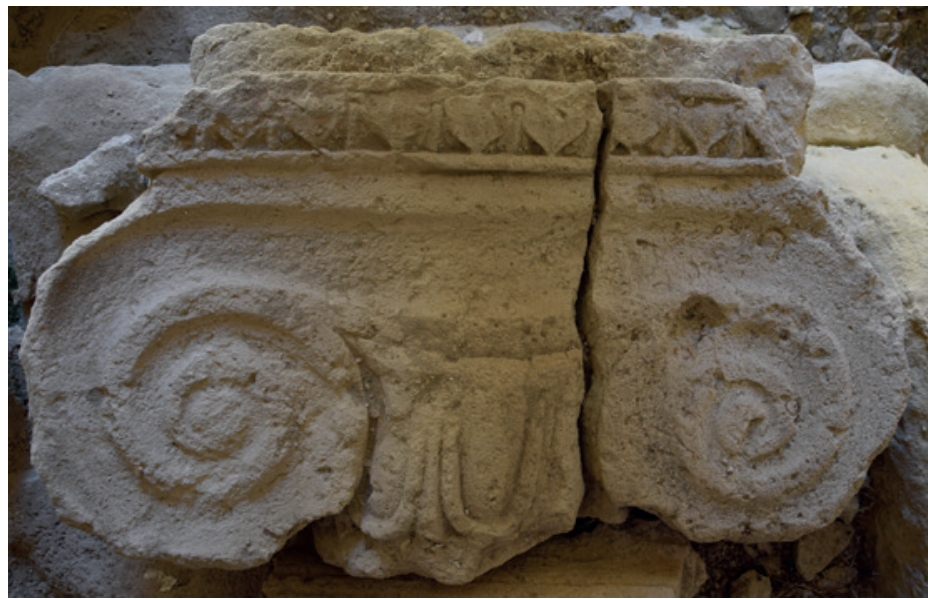

of the Ionic cyma compares well with the one of another capital from Tamassos in the Cyprus Museum at Nicosia. ${ }^{26}$

Much of the irregularity in the rendering of the Ionic cyma in Kourion might well be attributed to the fact that this piece comes not from a sanctuary, but from a private residence. If this is indeed the case, then it would indicate, as in the aforementioned Doric capital reused in the apsidal hall, a late-Hellenistic first phase of the Early Christian House.

\section{THE MODILLION}

The element (cat. no. 15, Fig. 24), placed in the lapidary along the western ambulatory of the peristyle, consists of a parallelepiped with about half of the rear sides left rough due to the fact that it would have been inserted into the wall. The front, on the other hand, is moulded at the top with a fascia and a cyma. The lower part, however, has a cyma on the front and side panels decorated with a circular ribbon-shaped tendril ending in the upper corner with three bunches of grapes resembling pinecones, decked in clover. The lower part is broken, so only the upper semicircle of the tendril is preserved.

Kourion is known to have another large modillion in the Nymphaeum at the Agora, which, due to the simplification of its mouldings, is certainly later. In the case treated here, the strong framing and naturalistic rendering of the tendril and the pinecones on the sides are suggestive of an earlier date. The upper surface is slightly poch-marked, but the front seems to have a slightly lowered rectangle that could indicate that a column once rested upon it. In this case one could easily imagine it forming part of a niche with a pediment supported by tiny columns.

${ }^{26}$ Michaelidou-Nicolaou 1970: 549, Fig. 1; Wright 1992: Pl. 295.3. See also a capital from Kition: Wright 1992: Pl. 292; Brzozowska 2016: 60, Fig. 13e. 


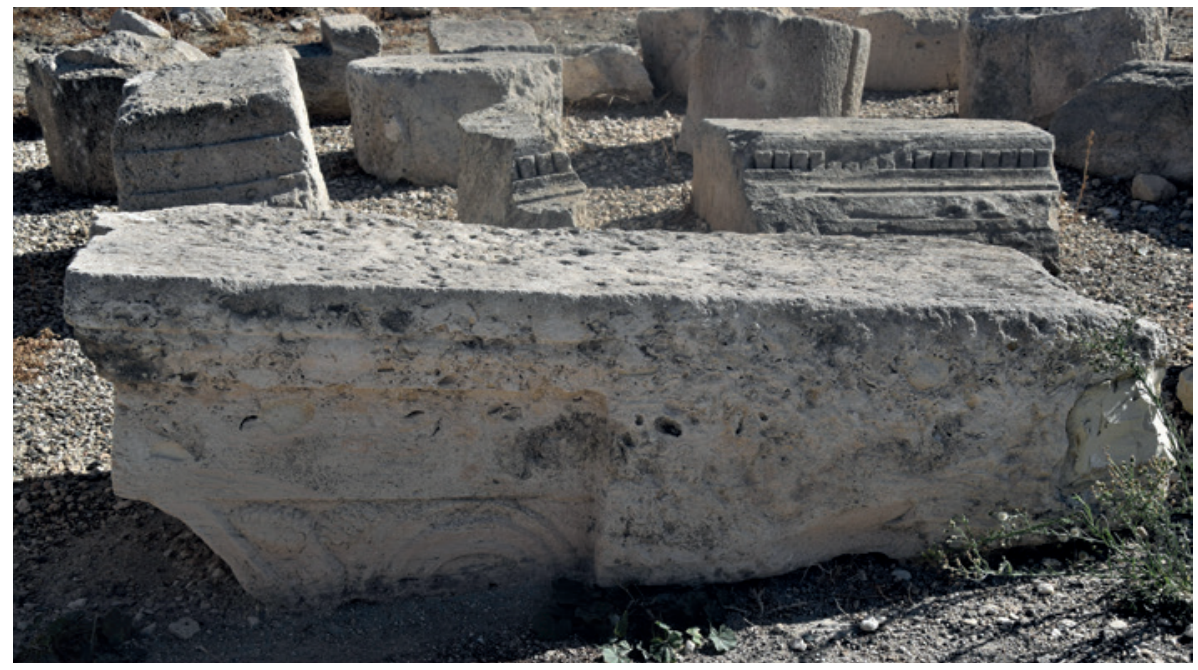

24. Modillion (cat. no. 15) from the lapidary along the ambulatory of the peristyle (Phot. P. Pensabene).

\section{CORNICES}

In the lapidary along the western ambulatory of the peristyle there are eight cornice fragments (cat. nos 14, 17a-f, 18, Fig. 25). In all these pieces the first moulding of the lower cornice consists of a line of dentils.

The best in the batch is cat. no. 14 (Fig. 25a), where the mouldings are sharp and accurately rendered, in particular the parallelepiped dentils, together with its plain ceiling and plain corona adorned with pedunculus. The corona is quite thin and separated by a schematic cyma reversa from the upper cyma recta, which has the convex curve that is strongly accentuated.

There is also a group of six fragments of the same cornice (cat. nos 17a-f, Fig. 25b), with rectangular dentils followed by a plain ovolo, on which there is a cyma serving as a moulded passage to the upper cornice that is preserved in three fragments. The upper cornice has a plain corona and ceiling and pedunculus and a cyma recta that is regular in shape.

If the elements described so far can be attributed to a horizontal entablature, a whole trapezoidal element is preserved belonging to an archivolt (cat. no. 18, Fig. 25c). It is possible that the element belonged to the archivolt of the half-dome of the apsidal room, but it cannot be excluded, given its amplitude, that the central opening of the tripartite portal of the colonnaded hall was equipped with an arch and that, therefore, the crowning of the portal was made up of a Syrian arch.

Two more cornice fragments (cat. nos 25, 28, Fig. 26) belong to a different type. They are characterised by flat rectangular modillions cut into the centre of the lacunar. One of them (cat. no. 25) has an elegantly stylised palmette with inwardly curving lobes. They are found in the stacks within the cryptoporticus, evidently created with the architectural 


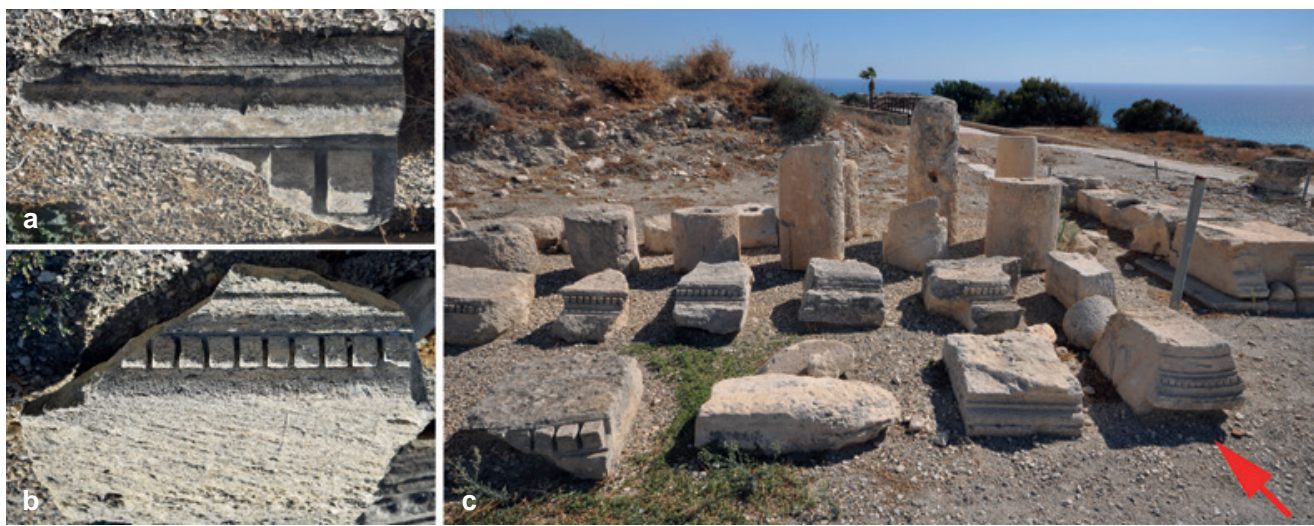

25. Cornices from the lapidary along the ambulatory of the peristyle: a. cat. no. 14; b. cat. no. 17a; c. general view, with cat. no. 18 indicated by the arrow (Phot. P. Pensabene).
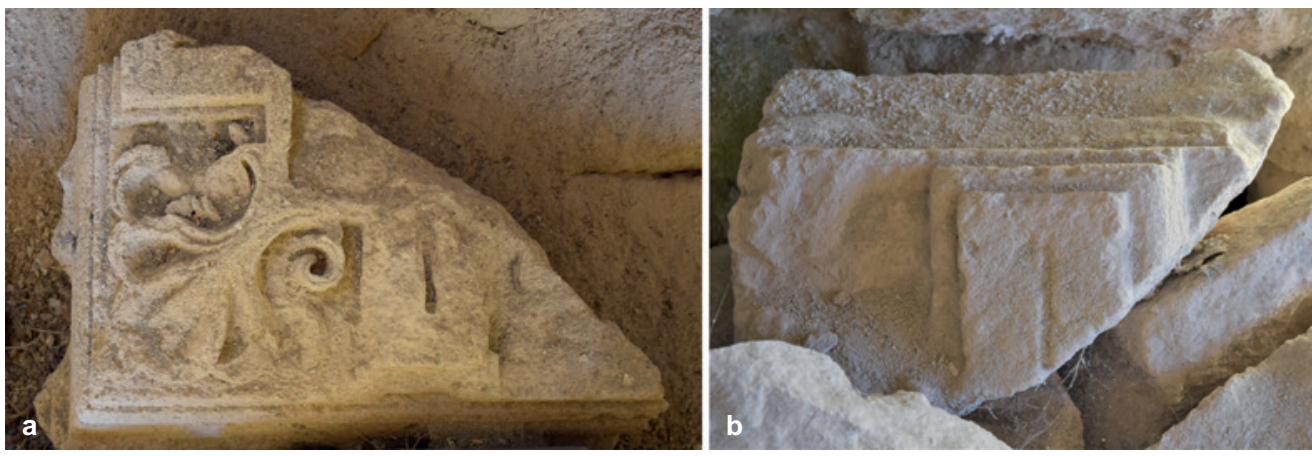

26. Cornices from the cryptoporticus: a. cat. no. 25; b. cat. no. 28 (Phot. P. Pensabene).

fragments found in the excavations of the fill, including parts of a simplified Corinthian capital and an Ionic capital (see above).

The cornices mentioned above fall into the two main categories that are most frequently encountered in Cypriot houses. ${ }^{27}$ The first group has no modillions, but rather the traditional moulding that comes to the fore in the late Hellenistic age, characterised by a cyma recta and a plain corona sometimes with a recessed ceiling that is traditionally called an Ionic cornice. The second group instead, with the so-called travicello modillions and variants of this type (flat rectangular modillions and meander modillions), is well known as being associated with the Alexandrian tradition..$^{28}$

${ }^{27}$ A detailed study of the examples from the House of Orpheus in Nea Paphos is now in progress by the authors in the Project directed by Monika Rekowska 'Residence as a self-presentation of urban elites. Architecture and decoration of the Orpheus House in Nea Paphos, the ancient capital of Cyprus', financed by the National Science Centre, Poland, project no. 2017/27/B/HS3/01131.

${ }^{28}$ For a synthesis on the Cypriot type, possessing consoles with travicello modillions, see also: Fuduli 2020: 170 . 


\section{THE STYLISTIC AND CHRONOLOGICAL FRAMEWORK}

One fact that emerges from the analysis of colonnaded hall of the Early Christian House is the application of the mixed order. The order diverges significantly from the Corinthian oeci known to us from paintings and from late Republican/early Imperial houses in Italy ${ }^{29}$ or even from the Palazzo delle Colonne in Ptolemais, ${ }^{30}$ where Alexandrian models are used, e.g. capitals that are either Corinthian or Corinthian-like. In this context should be recalled the Nabatean palace of Malichos I (59/58-30 BC) in Beidha near Petra, ${ }^{31}$ where the colonnaded hall also presents a double order of Corinthian columns and Corinthian heart-shaped pillars. In Cyprus, on the other hand, private houses, judging by the examples from Kourion and Paphos, are much closer to the less luxurious residences than the aforementioned palaces of Ptolemais and Beidha. Here Doric capitals were employed at the corners on heart-shaped pillars and simplified Corinthian capitals along the walls, on columns with Attic bases of two tori and without plinths. They seem to belong to the second century $\mathrm{AD}$, as will be suggested below. ${ }^{32}$

Simplified Corinthian capitals begin to spread in private buildings, imitating the sanctuaries that had been reconstructed on Cyprus after the earthquakes of the late first century $\mathrm{AD}$ or of the beginning of the second century AD. This rebuilding marks the definitive abandonment of the Alexandrian-Corinthian model, even in its local forms, by Cypriot workshops, which started then to adopt a simplified free Corinthian style ${ }^{33}$, as shown by the half-finished examples found in the quarries. ${ }^{34}$ At the time of their commissioning, they were probably vividly coloured, but the two disks in relief in the lower half prove that the products arrived at the construction site only partially worked, in that the protuberance, had they been completely finished, would have served to carve the top of the two crowns of acanthus leaves. In fact, beside the pattern of the two crowns, the Alexandrian model is also preserved in the four outer volutes, which are characterised by large plain leaves with the tip folded under the corners of the abacus.

The end of the first and the beginning of the second centuries $\mathrm{AD}$ is related to the phenomenon of marbling public architecture in the main cities of Cyprus. ${ }^{35}$ This is particularly well attested during the second century, especially from the Antonine Age onwards. As a consequence, among other things, private foundations employed in the elevations Corinthian and Ionic capitals, but the traditional schemes of the free Corinthian capital were replaced by the use of an acanthus influenced by a prickly Asiatic one. The time of this transformation might have been related to the construction of the so-called Market

\footnotetext{
${ }^{29}$ For a list of these examples and a comment see, most recently: Pesando 2017 and Cecconi 2020.

${ }^{30}$ Pensabene, Gasparini 2019 with further bibliography.

${ }^{31}$ Bikai, Kanellopoulos, Saunders 2008.

32 Cecconi 2020: Pl. I; on the Doric order at Nea Paphos, see also: Fuduli 2020: 169.

33 Pensabene, Gasparini 2020.

${ }^{34}$ Karagheorghis 1969: 498-499, Figs 135-136.

${ }^{35}$ See the sanctuaries, agorai, theatres, baths in the main cities of the island: Sinos et al. 1990; Christou 2013; Kiessel 2013; Barker 2016; Grawehr 2019.
} 

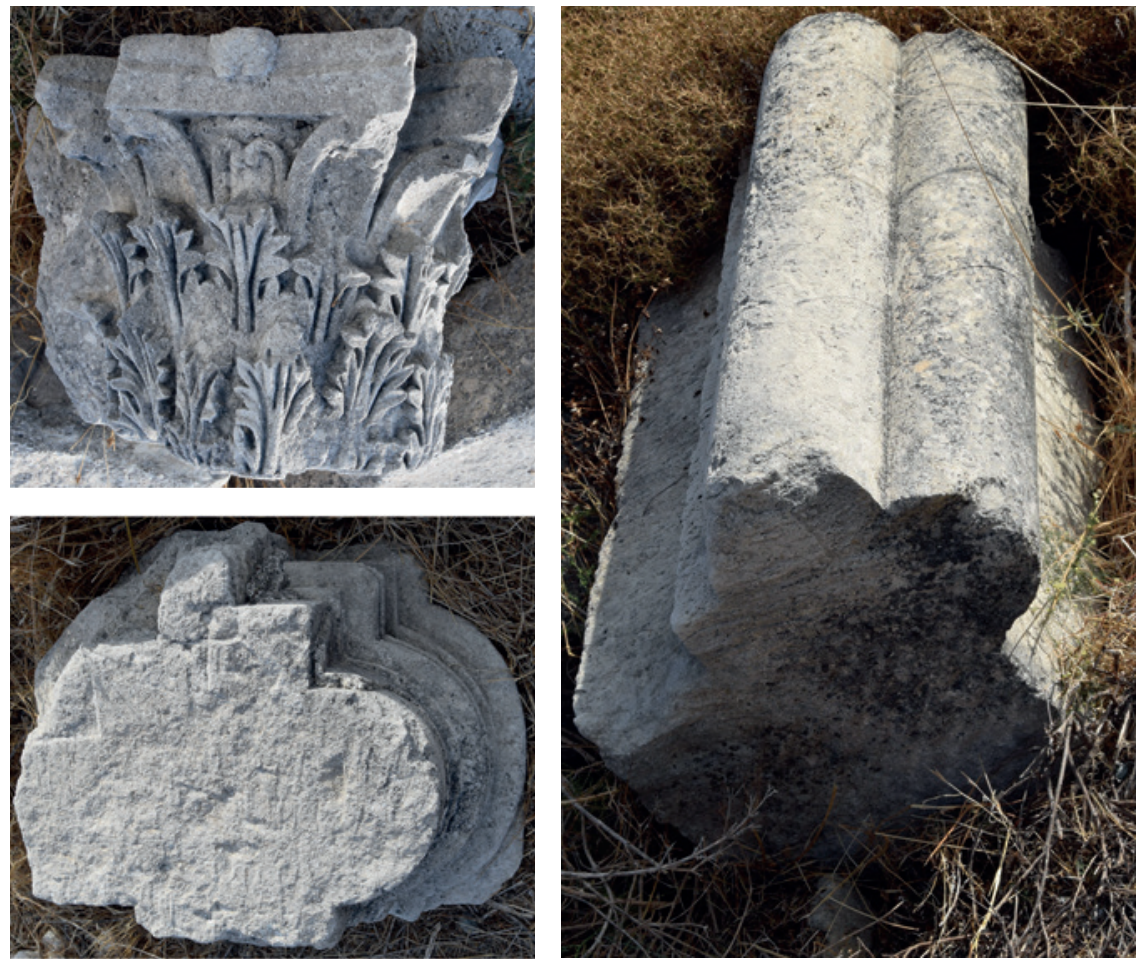

27. Angular pillars with engaged flat pilasters and half-columns from Kourion, 'Market Building' (Phot. P. Pensabene).

Building of Kourion, ${ }^{36}$ where there was a hall or court with angular pillars with engaged flat pilasters which in turn had engaged half-columns, according to a Hellenistic tradition that had been consolidated in Cyprus (Fig. 27). Upon these heart-shaped pillars, however, were Corinthian capitals with prickly acanthus leaves influenced by the Asiatic style (Fig. 27), even if adapted to fit the polylobate contour of the supports. These pillars, therefore, which are securely dated to the Antonine Age on the base of their capitals, ought to be considered later than those of the colonnaded hall of the Early Christian House. The hall must therefore have been conceived at a time when the influence of marble architectural decoration had not yet spread to the workshops using local stones.

Another confirmation of this hypothesis comes from the 'Hellenistic' House of Nea Paphos, a residence that was already obliterated and abandoned at the time of the construction of the Villa of Theseus, and whose first phase in our opinion dates to the second half of the second century BC on the base of the Alexandrian Corinthian Capitals that are reused on the main side of the peristyle in its later rearrangement. ${ }^{37}$

\footnotetext{
36 Soren, James 1988: Fig. on p. 138 and colour figures without page numbers.

${ }^{37}$ For the later phases, see: Brzozowska-Jawornicka 2019: 93-95; 2021.
} 
The peristyle of the 'Hellenistic' House in its last phase, that is to say after the Flavian earthquake, had a side - the north one - made up of half-columns with simplified Corinthian capitals. But in our attempt to understand how the use of a mixed order in the colonnaded hall of Kourion was possible, it should be emphasised that the various reconstructions of the peristyle of the 'Hellenistic' House had led to the introduction of different architectural orders on all four sides. At the same time, however, it preserved the original Rhodian plan, with the colonnade of the west side larger than the columns of the first order, at least on the south and east sides, where perhaps there was a second order of small columns, which could have balanced the difference in height. ${ }^{38}$ It seems, however, that the north side with its half-columns and simplified Corinthian capitals achieved the same height as the west side. ${ }^{39}$

The colonnaded room of Kourion must, therefore, have been formed at a time when the phenomenon of peristyles had been consolidated, whether it be those with a closed room plan or those with an open courtyard. In either case, the colonnades were aligned in a deliberately mixed order, characterised moreover by the continuity of the angular heart-shaped pillars. Given that the influence of marble architectural decoration had not yet spread to workshops using local stone, the period is clearly definable.

These chronological considerations are corroborated by the Doric capitals of Kourion's colonnaded hall. In fact, if we use the capitals of the underground peristyle tombs of the so-called Tombs of the Kings in Paphos as a reference, it becomes clear that as early as the first century AD, a modification of the traditional Doric form had taken place, following a trend that was also widespread elsewhere in the Mediterranean, but with specific Cypriot characteristics. In order to facilitate the processing, the common tendency was to replace the three anuli under the echinus with one or two fasciae. This led us to another, completely new, tradition, namely stucco coating of the columns. In Paphos, the smooth limestone plaster was applied in such a way as to make the columns look fluted. Generally, in Cyprus, particular types are provided with one, two or three small fasciae, with the upper fascia often overlapping the echinus, thus making it bipartite. In the Tombs of the Kings, with the exception of Tomb 8 (Ptolemaic in date and with Doric capitals that are either traditional with three anuli, or with a single fascia that replaces them) the funerary monuments, dated tentatively to between the first century $\mathrm{BC}$ and the first century $\mathrm{AD},{ }^{40}$ already show this transformation of the three anuli into a small fascia. Further chronological evidence comes from Nea Paphos, from the western sector of the House of Dionysos, preceding the end of the second century AD, so dated prior to the new phase with mosaics attributed to the early Severan Age, which overlaid previous structures. In the western part of this sector, simplified Corinthian capitals have been found, some in relationship to the heart-shaped pillars, which still preserve part of their thin stucco covering. ${ }^{41}$

\footnotetext{
38 Cf. Brzozowska-Jawornicka 2021: 103.

39 Brzozowska-Jawornicka 2019: 93-95; 2021: 103.

40 Guimier-Sorbets, Michaelides 2009: 218-225 with further references.

41 Pensabene forthcoming.
} 
Typological and chronological considerations could be proposed also by focusing on the evidence of the cornices. These observations are obviously very general and rough, but they represent the only base we possess for chronologically distinguishing the Cypriot cornices of the late Hellenistic period from the mid-Imperial period. In most of the cases the objects in question have been recycled, that is to say, reused in the masonry of another structure, due to reconstructions after earthquakes and are thus no longer in their original position. Moreover, one should also take into account that, as in many other foundation of the similar date from Cyprus, the same local stone was used until at least the second half of the second century AD, not only in private residences, but also in sanctuaries (for example that of Apollo Hylates in Kourion, of Aphrodite in Amathus and Zeus in Salamis) and in public monuments. Only in the late second century AD do novelties start to appear. Thereafter, one begins to see a pervasive use of imported marble and types unrelated to the Cypriot tradition in public architecture. Innovations also begin to appear in local stone entablatures, with the use of cyma recta modillions and a greater articulation of the lower cornice.

We have naturally taken into consideration the 'Hellenistic' House of Nea Paphos, which is one of the few residences where it was possible to reconstruct the position of the columns and entablatures, given that its obliteration (second century AD), at the time of the construction of the Villa of Theseus, led to the preservation almost in situ, of certain elements of the colonnaded courts, greatly facilitating the reconstruction work. ${ }^{42}$

In the houses of Cyprus, cornices without modillions and those of the Alexandrian group are attested in parallel. Depending on the context and the period, they influenced each other, both in design and decoration. The lower cornice appears to be more or less developed with or without dentil moulding, ovolo and cyma (especially plain or reversa). In the oldest examples only one or two mouldings appear, usually the dentil and the cyma, while in those that came later the lower cornice is more articulated and higher, with complex mouldings (dentil, ovolo, cyma or double cyma, etc). For both groups, the shape of the dentil can be used as a chronological indicator. Narrow and rectangular dentils are very similar in fact to the oldest specimens while quadrangular and sometimes square and more spaced out forms seem to be more recent examples. The ovolo can also offer information, not just stylistically, but also chronologically depending on its level of plasticity and position.

The cornices without modillions adhere generically to the styles forming part of the Hellenistic tradition, which during the first and second centuries AD are maintained with the canonical mouldings: these consist, in the upper cornice, in a cyma recta and a corona separated by a thin plain astragal or a listel, and, in the lower cornice, in a continuous dentil, or articulated in a series of quadrangular dentils, which can be followed by a cyma reversa or an ovolo and a cyma reversa and where some schematisations already present had to be corrected with a stucco coating. ${ }^{43}$ This group includes the cornices found in the

42 Brzozowska 2016; 2019: 94, Fig. 6; see also: Brzozowska-Jawornicka 2021.

${ }^{43}$ The same occurs in the Imperial period in the houses of Cyrenaica, for example at Cyrene and Ptolemais (Kraeling 1962; Mingazzini 1966). Furthermore, the excavations of the houses of Kom el-Dikka at Alexandria 
excavations of the Early Christian House, which for the limited development of the lower cornice - only a dentil and an ovolo - can still be attributed to the first half of the second century AD. A confirmation of this dating comes from the two fragments with flat modillions that had been hollowed in the centre (cat. nos 25, 28): the shape of both modillions and the angular palmette support this chronology.

\section{References}

Balmelle, C., Blanchard-Lemeé, M., Darmon, J.-P., Gozlan, S., Raynaud, M.-P 1985: Le décor geometrique de la mosaique romaine II : répertoire graphique et descriptif des décors centrés, Paris

Barker, C. 2016: The Theatre Precinct of Nea Paphos (Fabrika): Recent Excavations by the Australian Mission, [in:] Balandier, C. (Ed.), Nea Paphos. Fondation et développement urbanistique d'une ville chypriote de l'antiquité à nos jours Études archéologiques, historiques et patrimoniales. Actes du 1er colloque international sur Paphos Avignon 30, 31 octobre et 1er novembre 2012, Ausonius Mémoires 34, Bordeaux, 91-104

Bikai, P.M., Kanellopoulos, C., Saunders, S.L. 2008: Beidha in Jordan: A Dionysian Hall in a Nabatean Landscape, AJA 112, 465-507

Brzozowska, A. 2016: A Pseudo-Ionic Blocked-out Capital at Nea Paphos, EtudTrav XXIX, 43-65

Brzozowska-Jawornicka, A. 2019: Architecture of the Official Spaces of Selected Residences in Nea Paphos, Cyprus, Światowit LVIII, 87-105

Brzozowska-Jawornicka, A. 2021: 'Hellenistic' House in Nea Paphos, Cyprus - A First Summary of Its Architecture, EtudTrav XXXIV, 93-121

Buell, D.M., Mavromatis, Ch., Parks, D.A. 2010: The Kourion Mapping Project: a contextual spatial analysis of the Kourion acropolis, RDAC 2009, 261-294

Cecconi, N. 2020: Oecus Corinthius et Aegyptius: Origini, applicazioni e interpretazioni di due modelli architettonici in Italia e nel Mediterraneo meridionale e orientale tra Augusto e i Severi, Thiasos 9/2, 321-346

Christou, D. 2013: Anaskafés Kouríou 1975-1998, Nicosia

Fuduli, L. 2020: Some Observations on the Hellenistic Architecture of Nea Paphos. Tradition and Ptolemaic influences, [in:] Held, W. (Ed.), The Transition from the Achaemenid to the Hellenistic Period in the Levant, Cyprus, and Cilicia: Cultural Interruption or Continuity? Symposion at Philipps-Universität Marburg, October 12-15, 2017, Marburger Beiträge zur Archäologie 6, Marburg, 167-172

Grawehr, M. 2017: Bossenstil und Baumaterial, [in:] Kurapkat, D., Wulf-Rheidt, U. (Eds), Werkspuren. Materialverarbeitung und handwerkliches Wissen im Antiken Bauwesen, Diskussionen zur Archäologischen Bauforschung 12, Regensburg, 103-118

testify to how these two groups of cornices, described above, continued to be used during the early and middle Imperial Age (Tkaczow 2008). 
Grawehr, M. 2019: A Process of Glocalisation? Roman Marble Imports and the Rise of Blocked-Out Capitals in Local Stone, Światowit LVIII, 33-45

Guimier-Sorbets, A.-M., Michaelides, D. 2009: Alexandrian Influences on the Architecture and Decoration of the Hellenistic Tombs of Cyprus, [in:] Michaelides, D., Kassianidou, V., Merrillees S.R. (Eds), Proceedings of the International Conference Egypt and Cyprus in Antiquity, Nicosia, 3-6 April 2003, Oxford, 216-233

Karageorghis, V. 1969: Chronique des fouilles et découvertes archéologiques à Chypre en 1968, ВСH 93/2, 431-569

Karageorghis, V. 1974: Chronique des fouilles et découvertes archéologiques à Chypre en 1973, BCH 98/2, 821-896

Karageorghis, V. 1979: Chronique des fouilles et découvertes archéologiques à Chypre en 1978, BCH 103/2, 671-724

Karageorghis,V. 1987: A Guide To Kourion, Iacovou, M. (Ed.), Nicosia

Kiessel, M. 2013: Spätantike Kapitellausstattungen in Zypern. Das Thermen-Gymnasium von Salamis/Constantia und der Forumbereich von Kourion, Adalya 16, 241-260

Kraeling, C.H. 1962: Ptolemais: City of the Libyan Pentapolis, Chicago

Loulloupis, M.C. 1972: Limassol district, ARCypr 1972, 11-12

Michaelides, D. 1987: Cypriot Mosaics, Nicosia

Michaelides, D. 1988: Mosaic pavements of Early Christian cult buildings in Cyprus, [in:] Daszewski, W.A., Michaelides, D., Mosaic floors in Cyprus, Farioli Campanati, R. (Ed.), Ravenna, 79-151

Michaelides, D. 2020: Mosaic Workshops in Cyprus from the Fourth to the Seventh Centuries CE: Two Parallel Lives?, [in:] Nasrallah L., Luijendijk, A., Bakirtzis, Ch. (Eds), From Roman to Early Christian Cyprus, Studies in Religion and Archaeology, WUNT 437, Tübingen, 93-110

Michaelidou-Nicolaou, I. 1970: Une nouvelle table à jeu de Chypre, BCH 94/2, 549-550

Mingazzini, P. 1966: L’insula di Giasone Magno a Cirene, Roma

Młynarczyk, J. 1990: Nea Paphos in the Hellenistic Period, Nea Paphos III, Varsovie

Nicolaou, K. 1967: Excavations at Nea Paphos, The House of Dionysos, Outline of the Campaigns 1964-1965, RDAC 1967, 100-125

Pensabene, P. 1993: Elementi architettonici di Alessandria e di altri siti egiziani. Repertorio d'arte dell'Egitto greco-romano, Roma

Pensabene, P. forthcoming: Architecture and decoration of the houses in Cyprus from the Imperial Age: a preliminary study, [in:] Balandier, C., Michaelides, D., Raptou, S. (Eds), Nea Paphos and Western Cyprus, Proceedings of the International Colloquium, Paphos 11th-15th October 2017, Bordeaux

Pensabene, P., Gasparini, E. 2019: Houses, Architectural Orders and Opera Sectilia: Some Reflections on the Society of Cyrenaica and Egypt During the Imperial Period, [in:] Bąkowska-Czerner, G., Czerner, R. (Eds), Greco-Roman Cities at the Crossroads of Cultures. The 20th Anniversary of Polish-Egyptian Conservation Mission Marina El-Alamein, Oxford, 174-193 
Pensabene, P., Gasparini, E. 2020: Spreading of Alexandrian architectural types in the Eastern Mediterranean: the case of Cyprus [in:] Meyza, H. (Ed.), Decoration of Hellenistic and Roman Buildings in Cyprus, Travaux de l'Institut des Cultures Méditerranéennes et Orientales de l'Académie Polonaise des Sciences 4, WarsawWiesbaden, 151-165

Pesando, F. 2017: Peristili, esedre, saloni, basiliche private: echi dell'architettura palaziale greca nelle case di Pompei ed Ercolano, [in:] Osanna, M., Rescigno, C. (Eds), Pompei e i Greci, Milano, 343-348

Pesce, G. 1950: Il «Palazzo delle Colonne» in Tolemaide di Cirenaica, Roma

Sinos, S., Wenzel, F., Kalliri, E., Ieronymidou, M., 1990: The Temple of Apollo Hylates at Kourion and the Restoration of its South-West Corner, Athens

Soren, D., James, J. 1988: Kourion. In search of a lost Roman city, New York

Stephenson, J.W. 2014: Veiling the Late Roman House, Textile History 45/1, 3-31

Tkaczow, B. 2008: Architectural styles of ancient Alexandria. Elements of architectural decoration from Polish excavations at Kom el-Dikka (1960-1993), Alexandrie VIII, Warszawa

Wylde Swiny, H. (Ed.) 1982: An archaeological guide to the ancient Kourion area and the Akrotiri peninsula, Nicosia

Wright, G.R.H. 1992: Ancient Building in Cyprus, Leiden 


\section{APPENDIX: LIST OF ITEMS CONSIDERED}

A survey of the architectural elements preserved in the Early Christian House gave the minimum data necessary for the interpretation of the material. These data, collected during recording of the main architectural elements at the site, are listed below. Since the aim of this work is not a systematic cataloguing of every architectural element, we are not presenting here either homogeneous or complete data for each object, but just the list of the objects considered in the present paper with some additional information, in some cases consisting of basic measurements, while in others only of a brief description.

The architectural elements, all in local calcarenite, are divided according to the current position: some of them are still in situ, while others in secondary position. The contexts are the colonnaded hall (Fig. 2:1), the lapidary along the western ambulatory of the peristyle (Fig. 2:10), the apsidal hall and its vestibule (Fig. 2:2-3), the peristyle (Fig. 2:10-11), and the cryptoporticus (Fig. 2:11). In the cases of the lapidary and the assemblage from cryptoporticus, also of a random character, the localisation of particular items is clearly unimportant for interpretation so it was not specified.

\section{COLONNADED HALL}

1a-b. Two Attic half-bases and two Doric half-capitals of heart-shaped pillar (Figs 15a, 19). Localisation: NW corner.

Dimensions: bases $-30 \mathrm{~cm}$ high; pillar sides (from the corner) $-125 \mathrm{~cm}$ width; half-columns $-24 \mathrm{~cm}$ in diameter.

Commentary: The pillar base is carved from two blocks: the first comprises the base of the pillar and one of the half-bases, the other only the half-base. The capital of the pillar is carved out of the same block along with the two column half-capitals. On one of the outer sides of the upper corner of the pillar, almost in the centre of the capital of the protruding flat pilaster and on one of the half-capitals, there is a large groove. On the base of the flat pilaster the groove is missing. On the laying and supporting surfaces there are no holes for the clamps.

2. Two Attic half-bases of heart-shaped pillar (Fig. 16).

Localisation: SW corner.

Dimension: sides including half-columns $-124 \times 124 \mathrm{~cm}$; width of the bases of the engaged flat pilasters - lower side $96 \mathrm{~cm}$ and upper side $76 \mathrm{~cm}$.

Commentary: The half-base which projects on the south side is a separate block. On the supporting surface there are no holes for the clamps.

3. Two Doric half-capitals with a possible modillion on the back (Fig. 16).

Localisation: SW corner; over cat. no. 2 but not certain if they were originally related. Dimensions: total height, including the upper shaft $-37 \mathrm{~cm}$; upper shaft height $-17 \mathrm{~cm}$; upper shaft sides, including capitals - 83 x $83 \mathrm{~cm}$. 
Commentary: Unlike cat. no. 2, one could observe the crowning of an abutting pillar (modillion?). If this pillar went down to the base, then the discussed capital could not belong to the same pillar as the base upon which it currently rests, since it is devoid of any indications of the support which could have been placed on it. If, on the other hand, the protruding part was only relative to the capital, one could imagine its function as a modillion. On the laying surface there are no holes for the clamps.

\section{Column drum (Figs 9-10).}

Localisation: first column of the S side.

Dimensions: diameter $-45 \mathrm{~cm}$.

Commentary: The drum is smooth.

5. Column drum (Figs 9-10).

Localisation: Second column of the S side.

Dimensions: diameter $-50 \mathrm{~cm}$; height $-123 \mathrm{~cm}$.

Commentary: The drum is smooth.

6. Column drum (Figs 9-10).

Localisation: third column of the S side.

Dimensions: diameter $-45 \mathrm{~cm}$.

Commentary: The drum is smooth.

7. Two superimposed column drums (Figs 9-10).

Localisation: fourth column of the $\mathrm{S}$ side.

Dimensions: diameter $-48 \mathrm{~cm}$; total height $-85 \mathrm{~cm}$.

Commentary: The drums are smooth.

8. Simplified Corinthian capital (the so-called Nabatean), lower part (Fig. 20b).

Localisation: relocated to the third column on the S side (cat. no. 6).

Dimensions: diameter - from $43 \mathrm{~cm}$ (lower) to $67 \mathrm{~cm}$ (upper); height $-29.8 \mathrm{~cm}$.

9. Simplified Corinthian capital (the so-called Nabatean), lower part (Figs 15c, 20a). Localisation: relocated to the third column on the $\mathrm{N}$ side.

Dimensions: height $-22 \mathrm{~cm}$; diameter $-52 \mathrm{~cm}$ (lower), $75 \mathrm{~cm}$ (upper).

10. Simplified Corinthian capital (the so-called Nabatean), upper part (Fig. 22). Localisation: on the ground on S stylobate.

Dimensions: max. height $-45 \mathrm{~cm}$; lower sides: 48 x 51cm; abacus side: $95 \mathrm{~cm}$.

11. Simplified Corinthian capital (the so-called Nabatean), upper part (Fig. 22). Localisation: placed on fragment of cat. no. 10. 
Dimensions: max. height: $35 \mathrm{~cm}$; height of the abacus: $8.5 \mathrm{~cm}$; height of the volute under the corner: $11.5 \mathrm{~cm}$.

Commentary: corner of the abacus.

In the area of colonnaded hall, in addition to the elements inventoried above, there are four column shafts on the $\mathrm{N}$ side, two on the $\mathrm{W}$ side and ten columns bases (average height is 34-36cm) (Figs 9-10).

\section{LAPIDARY ALONG THE AMBULATORY OF THE PERISTYLE}

12. Simplified Corinthian capital (the so-called Nabatean), upper part (Fig. 17a). Dimensions: height $-42 \mathrm{~cm}$; lower sides -38 x $38 \mathrm{~cm}$.

13. Simplified Corinthian capital (the so-called Nabatean), upper part (Fig. 17b). Dimensions: max. height $-45 \mathrm{~cm}$; max. dimension of the sides $-61 \mathrm{x} 55 \mathrm{~cm}$.

14. Cornice with two rectangular dentils (Fig. 25a).

Dimensions: width $-52 \mathrm{~cm}$; depth $-18 \mathrm{~cm}$; dentils -7 x 7 x $7 \mathrm{~cm}$; distance between the dentils $-2 \mathrm{~cm}$.

15. Large modillion (Fig. 24).

Dimensions: length $-128 \mathrm{~cm}$; width $-56 \mathrm{~cm}$; height $-35 \mathrm{~cm}$.

16. Column shaft (Fig. 25c).

Dimensions: max. height $-89 \mathrm{~cm}$; diameter $-31 \mathrm{~cm}$.

17a-f. Six fragments of a cornice (Fig. 25b-c).

Commentary: Ten rectangular dentils (a), nine dentils (b), fourteen dentils (c), seven dentils (d), sixteen dentils (e), ten dentils and perhaps the plug of the eleventh and whole cyma recta, separated from the corona by a schematic cyma reversa that has a pedunculus (f).

18. Element of a cornice belonging to an archivolt (Fig. 25c).

Commentary: From bottom to top, it has two fasciae, one thick listel, a series of dentils and a fascia. The element must have formed part of a fairly wide arched tympanum because its curve is clearly visible, but not accentuated.

\section{APSIDAl HALL AND VestibUle}

19. Doric capital (Fig. 8).

Localisation: reused in the masonry.

Commentary: classicising in style, with three regular annuli; the grooves are flat. 
20-21. Two simplified Attic bases (Fig. 5).

Localisation: vestibule.

Commentary: Despite the poor state of preservation, it is possible to recognise the same sequence of mouldings of the bases of the colonnaded room and peristyle. It is noted that the scotia is flat and that the upper torus is reduced and not protruding.

\section{Peristyle}

22. Attic base of a pillar (Fig. 3).

Localisation: SW corner.

Commentary: carved from the same block as the lower shaft of the pillar. It is without a plinth and has two tori separated by a wide scotia, the upper part of which bears a thick listel. The listel protrudes from the reduced upper torus, which is separated by a thin cyma reversa from the lower shaft. There are grooves for inserting a screen.

\section{Attic base of a column (Fig. 4).}

Localisation: S wing.

Commentary: carved from the same block as the lower shaft of the column; without plinth; same type as cat. no. 22; grooves for inserting a screen.

\section{CRYPTOPORTICUS}

24. Ionic capital (Fig. 23).

Commentary: the different working of the Ionic cyma compared to the Lesbian one; decorating the abacus is perhaps due to a different hand.

25. Corner cornice (Fig. 26a).

Commentary: In the corner, between two flat travicello modillions, with median incisions, there is a stylised palmette, with inwardly curving lobes.

26. Simplified Corinthian capital (the so-called Nabatean), upper part (Fig. 22, top left corner).

Commentary: corner of the abacus.

27. Simplified Corinthian capital (the so-called Nabatean), lower part (Fig. 21).

Commentary: the upper shaft of the column with cylindrical disks on top of it.

28. Fragmentary cornice (Fig. 26b)

Commentary: fragment with flat travicello modillions and median incisions. 


\section{ÉTUDES et TRAVAUX XXXIV / 2021}
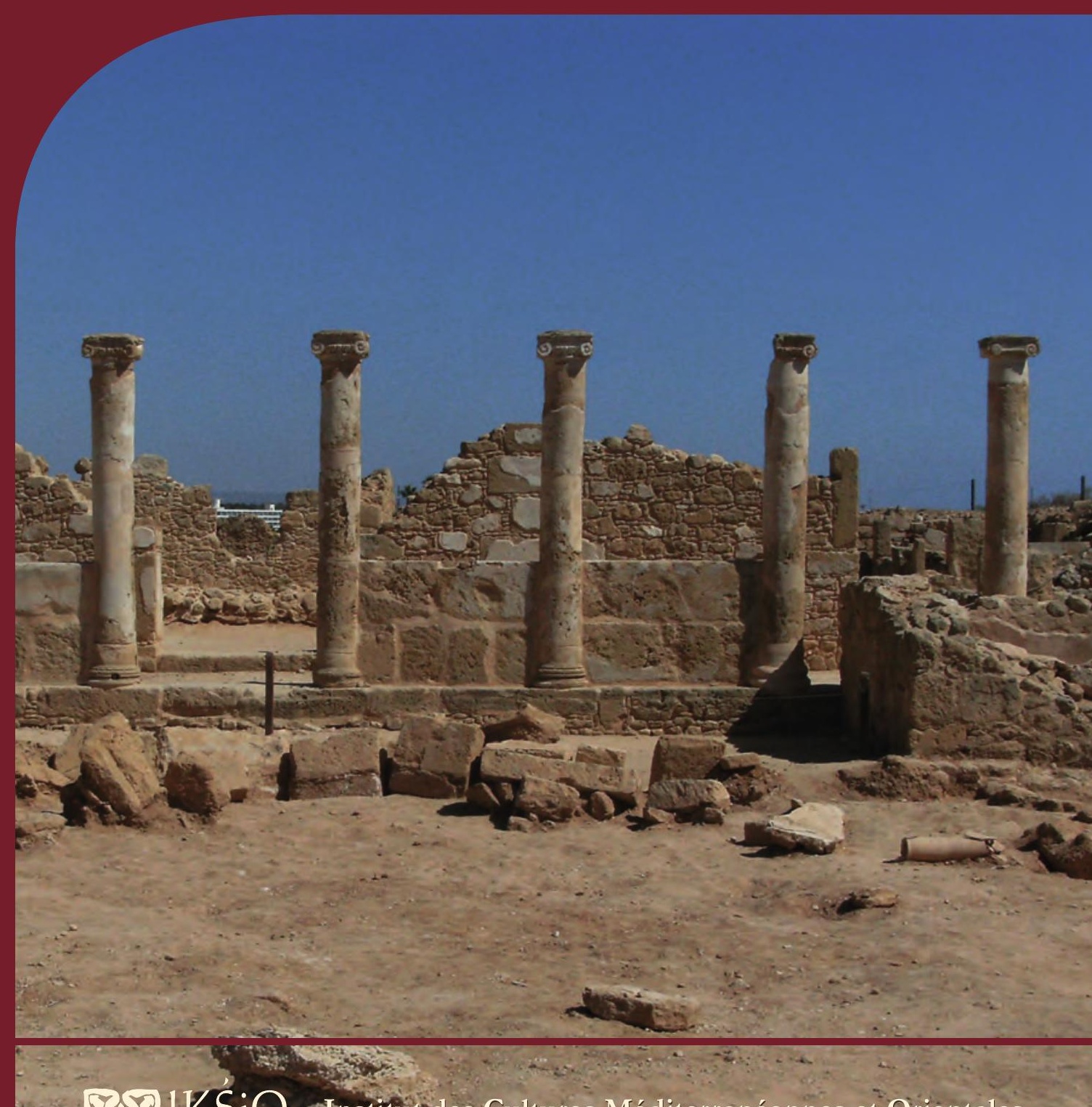

W $92 \mathrm{HKSiO}$ Institut des Cultures Méditerranéennes et Orientales

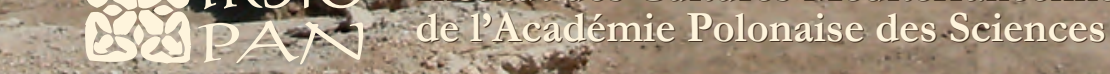

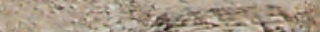

Q 
COMITÉ DE RÉDACTION SCIENTIFIQUE

Maciej Makowski - rédacteur en chef

Jadwiga Iwaszczuk - rédacteur

Katarzyna Kapiec - secrétaire de la rédaction

Henryk Meyza - rédacteur thématique du volume

CONSEIL SCIENTIFIQUE DU JOURNAL

M. Kobusiewicz (IAE PAN, Warszawa)

E. Laskowska-Kusztal (IMOC PAS, Warszawa)

D. Michaelides (University of Cyprus, Nicosia)

J.Ch. Moretti (IRAA-MOM, Université de Lyon 2/CNRS)

D. Raue (Ägyptisches Museum der Universität Leipzig)

P. Reynolds (ICREA, España)

D. Welsby (British Museum, London)

COMITÉ SCIENTIFIQUE DE LECTURE

la liste des membres du comité est accessible en ligne sur

http://www.etudesettravaux.iksiopan.pl

RÉDACTION TECHNIQUE

Marta Kaczanowicz

REVUE DES TEXTES EN ANGLAIS

Jo Harper 
ÉTUDES et TRAVAUX XXXIV 
INSTYTUT KULTUR ŚRÓDZIEMNOMORSKICH I ORIENTALNYCH POLSKIEJ AKADEMII NAUK

\title{
STUDIA i PRACE
}

\section{XXXIV}

\author{
GoIKSiO \\ QSO PAN \\ WARSZAWA \\ 2021
}


INSTITUT DES CULTURES MÉDITERRANÉENNES ET ORIENTALES DE L’ACADÉMIE POLONAISE DES SCIENCES

\section{ÉTUDES et TRAVAUX}

XXXIV

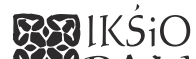

EOSPAN

VARSOVIE

2021 
Publication scientifique financée dans le cadre du programme du Ministre de la Science et de l’Éducation Supérieure

« Programme National de Développement de l’Humanistique » pour les années 2016-2021 (projet no 3bH 150099 83)

\title{
(1) NARODOWY PROGRAM ROZWOJU HUMANISTYKI
}

\author{
Copyright $(C)$ \\ Instytut Kultur Śródziemnomorskich i Orientalnych PAN \\ et les Auteurs \\ Warszawa 2021
}

ISSN 2084-6762

(jusqu'en 2011 : 0079-3566)

e-ISSN 2449-9579
Version première en papier, imprimée en Pologne - 150 copies
Version électronique accessible sur
http://www.etudesettravaux.iksiopan.pl

Édition: Polskie Towarzystwo Historyczne et Wydawnictwo Neriton, Warszawa

Conception générale de la couverture : J. Iwaszczuk

Photographie de couverture : Phot. A. Brzozowska-Jawornicka

(Le portique ionique est, péristyle de la Maison « hellénistique », Nea Paphos) 


\section{Table des matières}

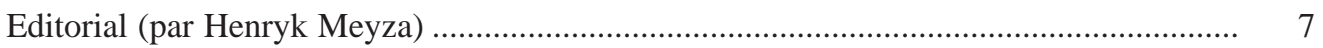

Marta BaJTLER

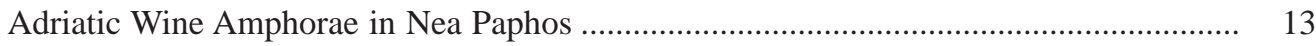

Claire Balandier, Jolanta MlynarczyK

The Temple and Its Surroundings on Fabrika Hill, Paphos: Preliminary Results

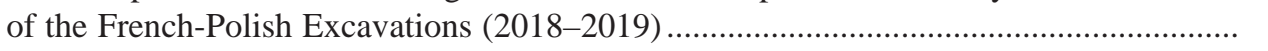

Grażyna BĄKowska-Czerner, Rafal CzERner

The Shell Motif in the Culture and Architecture of the Ancient Town of Marina el-Alamein in Egyp

AleKsandra BrzozowsKa-JaWornicKa

'Hellenistic' House in Nea Paphos, Cyprus - A First Summary of Its Architecture.

AleKsandra BrzozowsKa-JaWORnicKA, AnNa KuBICKA-SowińsKa

In Search of the Module in the Architectural Design of the 'Hellenistic'

House in Nea Paphos, Cyprus

RoKsana HaJduga

Kushite Stamp Impressions from Selib 2, Sudan

ERSIN HusSEIN

Mapping Metal Rich Roman Cyprus: The Case for Object-Centred Approaches

BARBARA LICHOCKA

Villa of Theseus at Nea Paphos (Cyprus). Fourth-Early Fifth Century Numismatic

Evidence for Architectural Transformations and Seismic Events

VASiliki Lysandrou, Demetrios Michaelides

Wall Paintings in Ancient Cyprus: The Hellenistic and Roman Tombs of Paphos

and Its Region

ADAM ŁAJTAR

A Weight of Seleucia in Pieria in Nea Paphos

Diana MroczeK

Ancient Portrait Busts of Marcus Aurelius in the National Museum in Poznań 
Brandon R. Olson, R. Scott Moore, Thomas Landvatter, Justin Stephens

Pyla-Vigla: A Case Study Assessing the Imperial Strategies of the Hellenistic

Diadochoi in Cyprus

Patrizio Pensabene, Eleonora Gasparini

Colonnaded Hall in Kourion: How the Oecus Corinthius Was Interpreted in the Roman

Houses of Cyprus

Monika Rekowska, Demetrios Michaelides, Skevi Christodoulou, JAKUB KANISZEWSKI

Adopting Roman Habits - The Baths in the House of Orpheus in Nea Paphos

as a 'Troublesome' Case Study?

MARCIN M. ROMANIUK

Terracotta Pipelines at Maloutena: Remarks on the Water System in the

Residential District of Ancient Nea Paphos, Cyprus

363

ABRÉVIATIONS

407 